\title{
Building a Coalition with Depoliticized Sustainability Discourse: The Case of a Transdisciplinary Transition Management Arena in Peru
}

\author{
Eduardo Noboa ${ }^{1}$, Paul Upham ${ }^{2} \&$ Harald Heinrichs ${ }^{1}$ \\ ${ }^{1}$ Institute for Sustainability Governance (INSUGO), Leuphana University Luneburg, Universitätsalle 1, 21335 \\ Luneburg, Germany \\ ${ }^{2}$ Institute for Environmental and Sustainability Communication (INFU), Leuphana University Luneburg, \\ Universitätsalle 1, 21335 Luneburg, Germany \\ Correspondence: Eduardo Noboa, Institute for Sustainability Governance (INSUGO), Leuphana University \\ Luneburg, Universitätsalle 1, 21335 Luneburg, Germany. Tel: 49-151-5482-9194. E-mail: noboa@leuphana.de
}

Received: October 30, 2018

Accepted: December 17, 2018

Online Published: January 31, 2019

doi:10.5539/jsd.v12n1p84

URL: https://doi.org/10.5539/jsd.v12n1p84

\begin{abstract}
Transition management uses the depoliticized, rational discourse of systems terms, social learning and societal reflexivity. Transdisciplinary sustainability science research similarly uses the politically neutral terms of supporting the coproduction and integration of different types of knowledge. Yet both are clearly normative, resting on notions of participatory democracy and adopting environmental and social sustainability as explicit norms. Here we present the case of a transdisciplinary transition management arena in Peru, convened to develop a vision of a lower carbon, more decentralized and resilient national energy system. We show how the characteristics of the arena can help to foster the necessary conditions for empowerment and how these in turn both support - and are supported by - the ability of participants from different backgrounds generate shared problem statements, visions and strategies, building towards a coalition for change. While it remains to be seen how politically influential such arenas can be in the medium and long term, we show that depoliticized, rational sustainability discourse nonetheless has a political role to play in helping to legitimize informal institutional efforts towards energy policy change.

Highlights

Transition management and transdisciplinary sustainability science rationales are complementary

These rationales are integrated in a Transdisciplinary Transition Management Arena (TTMA) framework

The TTMA is applied with Peruvian energy system stakeholders holding marginalised views on energy futures

A vision for a low carbon Peru is developed that emphasises the inclusion of distributed renewables

The TTMA is assessed in terms of its capacity to support conditions for the empowerment of marginalised policy stakeholders
\end{abstract}

Keywords: Peru, transdisciplinary transition arena, energy democracy visions, empowerment

\section{Introduction}

Transition Management (Kemp, Loorbach, \& Rotmans, 2007) is premised on a co-evolutionary conception of socio-technical change, in which 'transition' is understood as shifts or system innovations between distinctive socio-technical configurations encompassing not only new technologies, but also corresponding changes in markets, user practices, policy and cultural discourses, as well as governing institutions (Loorbach \& Rotmans, 2010). (Geels \& Schot, 2010) characterize transitions as following: (1) co-evolution and multiple changes in socio-technical systems or configurations, (2) multi-actor interactions between social groups including firms, user groups, scientific communities, policy makers, social movements and special interest groups, (3) 'radical' change in terms of scope of change (not speed), and (4) long-term processes over 40-50-year periods.

Those seeking to implement transition management would examine the possibilities for change in terms of three types of governance activities - strategic, tactical and operational - which as a framework are intended to provide a structure for analysis (Kemp et al., 2007). 
1) Strategic level: processes of vision development, strategic discussions, long-term goal formulation, culture change etc.; this includes governance activities related to long-term changes, which are not institutionalized in regular political cycles and have a time horizon of 30-50 years;

2) Tactical level: processes of agenda building, negotiating, networking, coalition building, identification of 'barriers' etc.; this includes steering actions (planning and control, financial support and programs) and institutions (rules, regulations, organizations, networks, routines, infrastructure) related to the dominant sociotechnical regime and have a time horizon of 5-15 years;

3) Operational level: processes of experimenting, project building, implementation of governance, and autonomous actions to achieve individual goals, etc.; this is the level of radical innovation, referring to activities with a time horizon of up to 5 years.

Despite the systems and managerial discourse, in practice transition management is political in the sense of seeking to intervene in the power to act. Hence Avelino and Rotmans (Avelino \& Rotmans, 2009) argue that while instrumental, structuralist and discursive understandings of power differ, each has informative implications for how power is conceived in the context of transitions. Moreover, this is so even when transition management is intended to be consensual. Characteristically, transition management involves the engagement of civil society stakeholders in the meaningful engagement and co-construction of more sustainable futures (Hölscher, Wittmayer, Avelino, \& Giezen, 2015). That is, the intention is that civil society may be empowered through the provision of 'experimental' fora or platforms that create new opportunity structures (Narayan-Parker, 2005), in which civil society actors can forge new agency-networks amongst themselves and also often with governmental actors (Frantzeskaki \& Kabisch, 2016). These typically connect local, intermediary and state levels and investigate or even trial options that those that are legally mandated (Alsop, R., Bertelsen, M. F., \& Holland, 2006).

Similarly, regarding facilitating conditions in transition management-like processes that include an open discussion format that enables sharing, the inclusivity of actors from multiple disciplines and with different expertise and experiences, and the legitimacy of the knowledge contributed to the co-production process, these are all consistent with a particular view of deliberative democracy that extends beyond representation and involves direct engagement (Dryzek, 1990), (Bohman, 1996), (Barber, 1984). Thus, the perspective of transition management is strongly linked to the discourse and practice of participation and sustainable development, which highlights the need for participatory approaches in view of factual and social complexity of sustainability challenges. Transition management has much in common with transdisciplinary (typically sustainability science) research, of which the same can be said.

As Patterson et al (2017) describe, transformations towards sustainability are deeply political (Scoones, Leach, \& Newell, 2015)(Leach et al., 2012)(Meadowcroft, 2009)(Schellnhuber et al., 2011), because transformations are likely to have redistributional impacts, resulting in winners and losers (Meadowcroft, 2011)(Van den Bergh, Truffer, \& Kallis, 2011). Normative sustainability goals require a political response (Schulz \& Siriwardane, 2015) and such responses originate from particular political perspectives, worldviews and values, all of which condition ideas of what constitutes a desirable future (Hulme, 2009)(Stirling, 2011)(Stirling, 2014)(Patterson et al., 2017).

Given this, transdisciplinary formats are intended to encourage reflexivity as part of consensus building (Popa, Guillermin, \& Dedeurwaerdere, 2015). That is, to support critical reflection on participants' values and orientation as well as the ability to adapt one's own positions and goals, thereby supporting and enabling capacities for purposive, collective action (Patterson et al., 2017). This in turn is theorized to involve and develop the capacity to anticipate problems and integrate different types and sources of knowledge.

Transdisciplinary research has aims similar to those of transition management as well: to develop socially robust solutions for sustainable transitions via mutual learning, social reflexivity, empowerment and the building of social capital (Roland W Scholz, 2017). However, transdisciplinary research centres on the integration of the different types of knowledge and ways of knowing used by scientific researchers and practitioners. As such, transdisciplinary research emphasizes the role of scientific researchers and more generally of different types of knowledge, as "inducing processes of strategic (societal) transition when including certain stakeholder groups." (Roland W Scholz \& Tietje, 2002). The two perspectives also concur in their shared acknowledgement of knowledge and the generation of new knowledge as a particularly valuable form of social capital. The drive for this may arise, for example, from disappointment with formal public participation outcomes, leading to the initiation of informal grassroots participatory initiatives intended to intervene in planning-related decision making (Berman, 2018) and also - arguably more by implication than overtly - empower relatively marginalized 
actors. (Batliwala et al., 1995) defines empowerment as "a spiral, changing consciousness, identifying areas to target for change, planning strategies, acting for change, and analysing activities and outcomes", perfectly aligning with the aims of transdisciplinary research.

While there is a wide range of definitions of transdisciplinarity, as Scholz and Steiner (2015) observe, in general transdisciplinary processes are expected to generate socially robust orientations that are science-based, state-of-the-art, socially accepted options of solutions cognizant of uncertainties and the incompleteness of different epistemics (Roland W Scholz \& Steiner, 2015a).

Njoroge et al. and Steelman et al. (Njoroge et al., 2015)(Steelman et al., 2015) address transdisciplinary sustainability research processes as practised in developing countries, advocating that the core aspects of transdisciplinarity (Klein et al., 2001)(R.W. Scholz et al., 2011) (Roland W Scholz, Lang, Wiek, Walter, \& Stauffacher, 2006)(Klein et al. 2001; Scholz 2011; Scholz et al. 2006) are applied, namely that there is project co-leadership of the research process, with representatives from both practice and science participating in all subprojects and activities on an equal footing; and that representatives from all key stakeholder groups are included, for reasons of both including the necessary knowledge and obtaining the multiple perspectives of the various stakeholders necessary for socially robust responses.

Given the history of the development of the concept of transdisciplinarity, notably including the Zurich 2000 Conference (Klein et al., 2001), as said a key feature of transdisciplinarity is not simply that practitioners are invited to participate in research, but that there is a co-definition of the goals of the transdisciplinary research or process, the forms of which are ideally defined as involving co-leadership.

With this in mind, here we present the case of a transdisciplinary transition management arena in Peru, initiated as a transdisciplinary scientific project and convened to develop a vision of a lower carbon, more decentralized and resilient national energy system. The process focused primarily on the co-production of knowledge, while the initial co-definition of goals was only partially participatory, defined by a sub-group of participants. We describe and analyse how participants from different backgrounds generate shared problem statements, visions and strategies, building a coalition for change that motivated several participants to take joint political action immediately. Our main theoretical research question is: in what ways might transition management and transdisciplinary (sustainability science) research support political empowerment, despite its neutral political discourse? Our main empirical research question is: what might a low carbon energy future for Peru look like, if a section of society broader than currently controls key aspects of energy policy were given more influence?

In terms of the structure of the paper, we begin with an overview of power in action, as applied to sociotechnical sustainability transitions processes by Avelino and Rotmans (2009). To this we connect concepts of empowerment by several authors working outside of sociotechnical transitions framing. It is the potential for at least the beginnings of empowerment that we attribute to (transdisciplinary) transition management arenas and that we explore empirically. To this end, we outline the nature of the Peruvian energy system and then describe the transdisciplinary transition management arena developed and applied to serve as a protective space for the development of new energy policy directions. We summarise its energy policy recommendations and describe its effectiveness as perceived by participants - which we interpret as evidence of at least the beginnings of empowerment. Finally, we reflect on the implications for transition management processes in situations that differ from the northern European conditions in which the idea and practice evolved.

\section{Power, Empowerment and the Peruvian Energy Transition Context}

Contemporary political theorists have argued that depoliticized discourses have been hegemonic over the last decades (Kenis, Bono, \& Mathijs, 2016). For example in the environmental sphere, the discourses and calculation methods of carbon trading, emissions reduction from deforestation and degradation (REDD + ), the Clean Development Mechanism, while all having their merits, arguably side-step value judgements relating to fungibility, sufficiency, individual voluntary responsibility and so on (e.g. (Swyngedouw, 2010)). Such measures arguably have a particular political-philosophical background (namely neo-liberal market economics) and thus support corresponding political structures, despite depoliticized discourse (ibid).

While sociotechnical transition management seeks a redirection of economies in sustainable directions, it too uses a language of systems that appears neutral. Cognizant of this tendency towards depoliticization, (Avelino \& Rotmans, 2009) offer a framework for thinking about power in transition management. Accordingly the authors define power as the ability of actors to mobilize resources in order to achieve particular goals and that this requires resources that may be of many different types (Avelino \& Rotmans, 2009). These resources may be used to create or discover resources (innovative power), perhaps by making something more visible (ibid). Alternatively, resources may be used destroy other resources (destructive power), through violence or other 
removal of the option to use (ibid). In addition, constitutive power is defined as the capacity to institute or stabilise a distribution of resources and transformative power as the ability to transform the distribution of resources. Systemic power is defined as the 'combined' capacity of actors to mobilize resources for the survival of a societal system, which may be a nation, sector, business etc. (ibid).

While Avelino and Rotmans (ibid) usefully characterise different types of power, the capacity to exercise this remains contingent on empowerment in the sense of a belief that meaningful action is possible (Ibrahim \& Alkire, 2007). It is in this respect that transition management arenas may help (here, transdisciplinary arenas in the sense of academics working with practitioners), especially in contexts where civil society is weak and policy options that are alternatives to those currently institutionalised are particularly marginalised (Hölscher et al., 2015). Such conditions are typical of illiberal democracies (Noboa \& Upham, 2018).

Here we define such empowerment as beginning with an enhanced perception of self-efficacy that comes about through the identification of conditions that enable the exercise of outer-directed power (Conger \& Kanungo, 1988). In other words, the beginning of a sense of empowerment requires that actors can see what needs to change and how that change may be affected. The stage beyond this is action-enabled empowerment, which Malhotra and Cross (2005) define as: "the enhancement of assets and capabilities of diverse individuals and groups to engage, influence, and hold accountable the institutions that affect them." This is a more general statement of empowerment as operationalized by Avelino and Rotmans (2009). Figure 1 sets out a synthesis of the two stages of empowerment, bringing together the concepts of (Conger \& Kanungo, 1988) and Avelino and Rotmans (2009).

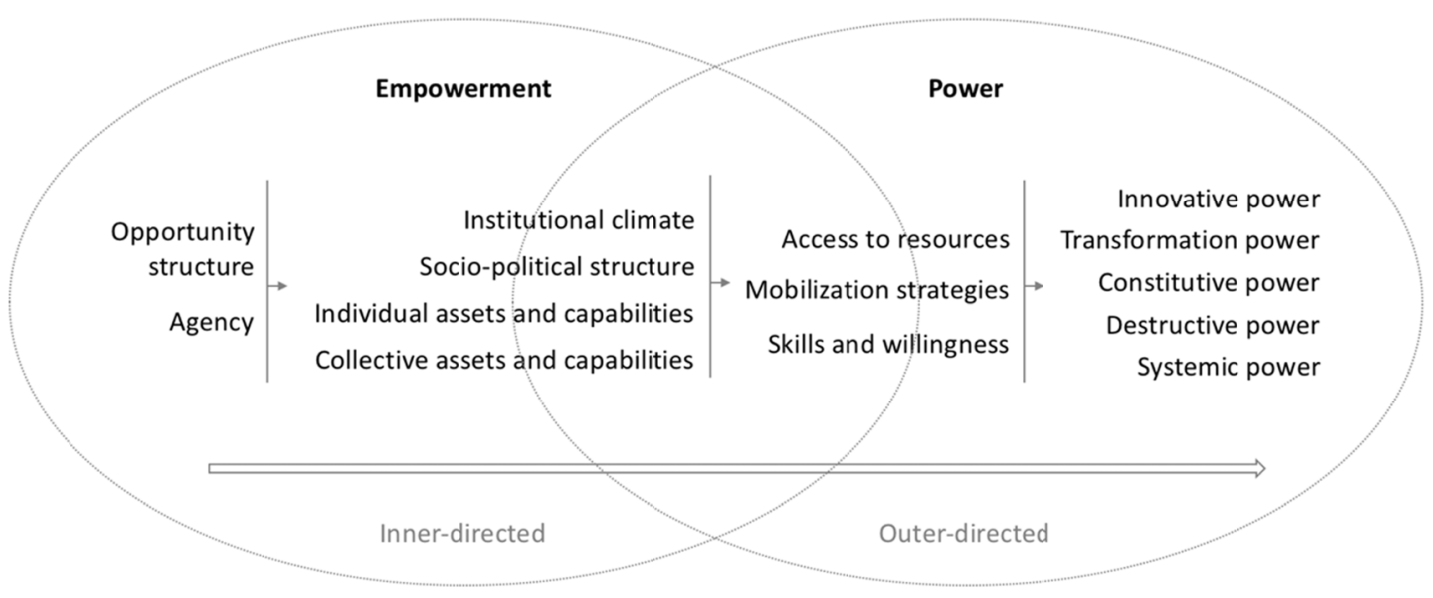

Figure 1. Empowering the exercise of power

In the terms of Avelino and Rotmans (2009), the Peruvian energy system is one of concentrated, stable systemic power, with constitutive power being held by a small number of actors. These are principally involved in oil and gas extraction, major recipients of foreign direct investment via transnational companies and also large-scale hydropower. In 2015, Peruvian demand for electricity was 48,251 GWh per year, of which 21,726 GWh was supplied by natural gas fired power stations and 23,711 GWh by large hydropower (IEA, 2015). The level of governmental interest in pursuing a low carbon economy might also be inferred from the length of time taken to approve (not implement) the Law 27345 that promotes efficient energy use, namely seven years. The current National Energy plan for 2014-2025 should be implemented between 2018 and 2025 but has a severely reduced budget (Ríos Villacorta, 2016).

Regarding the climate policy context, the first National Climate Change Strategy (ENCC) came into force in 2003 and was revised in 2009 and 2014, when Peru hosted the COP20. The major objective of the ENCC is to reduce the adverse impact of the climate change by: (1) identifying the most vulnerable zones and/or sectors where adaptation programs need to be implemented; (2) controlling greenhouse gas emissions through programs that promote renewable energies and energy efficiency in all economic sectors. The ENCC contains 11 action strategies that propose measures for a more 'rational' management of greenhouse gas emissions, better management of forests for increased carbon sequestration, and distribution of knowledge and information about climate change (MINAM, 2014). 
A major step towards a more sustainable oriented energy system was the adoption of the Law 2001 (Law 1002) in 2008. This was actualized in March 2011 by the Supreme Decree $N^{\circ}$ 012-2011-EM, of which Article 2 states that the Ministry of Energy and Mines (MINEM) should establish an objective percentage of Renewable Energy Resources (RER) and that this should be updated every five years. For the first five years a $5 \%$ target was established, despite RER, particularly wind energy, having far greater potential (Ríos Villacorta, 2016).

Article 5 establishes a priority of RER in the daily office of the Committee Responsible for the Economic Operation (COES SINAC) of the National Interconnected Electric System (SEIN) and an established price for RER. Article 7 specifies that the said guaranteed price should be evaluated through auctions where different projects should compete for quotations to inject energy into the National Interconnected Electric System. These auctions should be held at least every two years by the Supervisory Body for Investment in Energy and Mining (OSINERGMIN), and the resulting prices valid for a period of 20 years. In 2016, eight years after the adoption of Law 2001, the elaboration and implementations of plans and programs for the investment into research and university programs concerning RER as called for in article 10 and 12 had hardly advanced (Ríos Villacorta, 2016).

Moreover, it is large scale hydropower that has been favoured for reaching RER targets. Peru's Ministry of Energy and Mines has commissioned tenders for $1100 \mathrm{MW}$ of hydroelectric power plants that should come on-line by 2018/2019. As a long run strategy, according to MEF (2011), the structure of the electricity by 2040 mix should be: $40 \%$ hydroelectricity, $40 \%$ natural gas, and $20 \%$ nonconventional renewable energy (NCRE) (Chavez-Rodriguez et al., 2018).

Against the policy backdrop of slow progress to RER targets and under-utilisation of other, particularly smaller scale and decentralized renewable energy options, our premise is that transdisciplinary transition arenas have the potential to play a role in catalysing system change, even if that role is modest in terms of any of the forms of power identified by (Avelino \& Rotmans, 2009). The way in which we envisage such arenas exerting power is not so much through the direct exercise of creative, destructive and transformative power (Avelino \& Rotmans, 2009), but, more plausibly, by helping to create the conditions for this. With a stable regime of centralised energy supply, such arenas are likely to be limited in their effectiveness, but nonetheless they do have the capacity to make marginalised voices more visible, a key feature of innovative power as defined above. Such arenas also help to create the coalitions and social capital that meaningful political engagement and action requires. With this in mind, in the next section we describe the rationale and nature of the arena developed and assessed here.

\section{Material and Methods}

The overall research design is intended to support the experimental deployment and evaluation of a transdisciplinary transitions arena capable of producing less centralized, lower carbon energy policies for the Peruvian energy system. In using the term transdisciplinary transition management arena (TTMA), we acknowledge the variety of experiments that this term embraces (Caniglia et al, 2017). Evidence regarding the effectiveness of the arena is presented here from the perspectives of the participants, but using theoretically-derived criteria based in selected empowerment and power-related frameworks (Avelino \& Rotmans, 2009) (Narayan-Parker, 2005)(Alsop, R., Bertelsen, M. F., \& Holland, 2006). Mixed methods were used, specifically participant observation of the arena process, from which the appended policy and related information was derived; post-hoc questionnaires provided data on self-assessment of the process by the participants. 


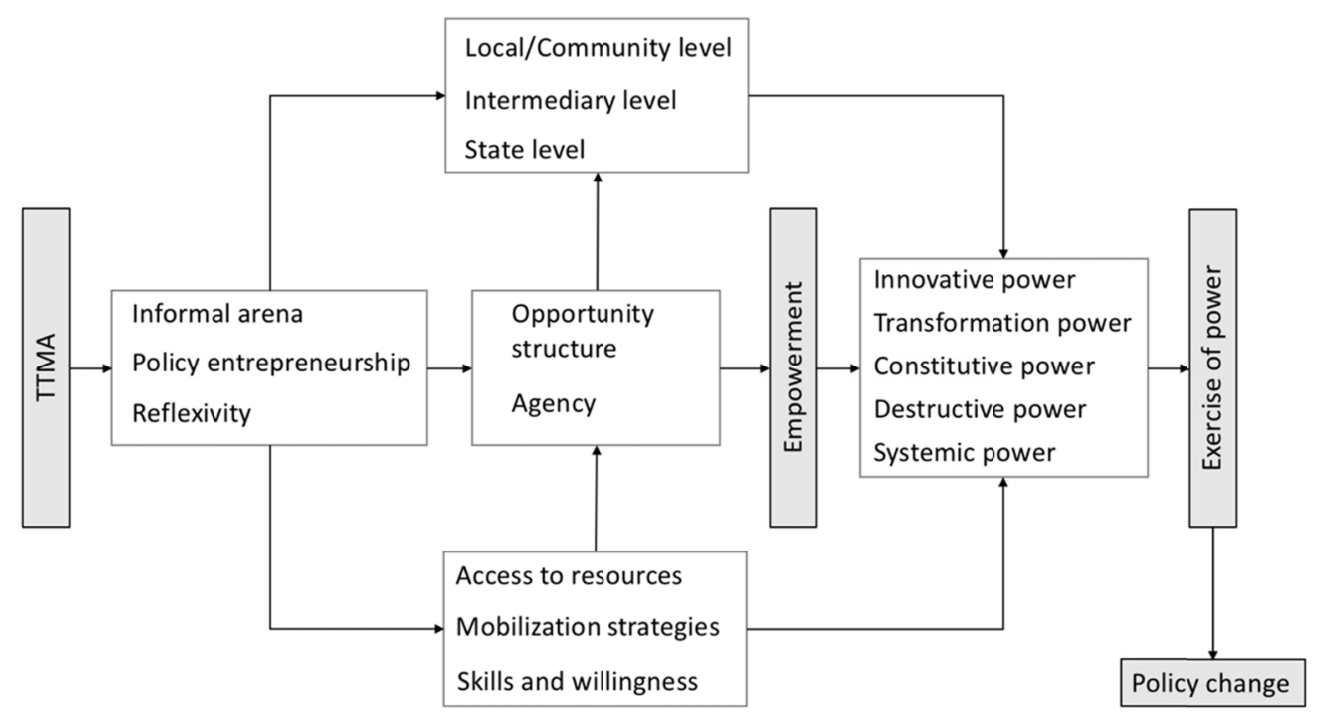

Figure 2. Linkages between empowerment and power-relations in Transdisciplinary Transition Management Arenas (TTMA)

Characterizing the process in terms of the transdisciplinary literature, while for (R.W. Scholz et al., 2011), modes of theory-practice collaboration in this case are close to action research as a result of the involvement of decision-makers, the latter were not in a position to make formal policy decisions. Rather the arena was intended as the first phase of a longer process; and, moreover, given the political context, the transdisciplinary process is politically highly marginal relative to formal institutions It can be noted in this regard that the link between transition research as an activist science endeavour and post-positivist (Lewin, 1945) and the reflective scientist perspective of transdisciplinarity, with its interpretative approach and forward-looking, constructivist, reflective equilibrium between theory and practice, often involving formative scenario analysis (R.W. Scholz et al., 2011) is an analytic frame that supports multi-sectoral, formative preference processes (Dedeurwaerdere, 2018).

As such, the arena has been set up to provide a space for dialogue and the co-production of knowledge that seeks to support the transition processes involved the energy development model formulated under the National Planned and Determined Contribution (NDC) and its articulation within the new local and global context. As a cross-sectoral strategy, the process of developing the NDC provided a space for participation and dialogue in which stakeholders from academia, government, private sector, trade unions and civil society were invited to jointly construct alternative GHG emission scenarios and identify mitigation options and adaptation goals in the main sectors: agriculture, energy, forestry, industrial processes, transportation and waste, in order to meet the United Nations Framework Convention for Climate Change (UNFCCC) international commitment to submit its National Planned and Determined Contribution. Peru, as other UNFCCC member states, is in the process of reviewing and readjusting its NDC (NDCs of member countries are the basis of the Paris Agreement to enter into force in 2020), associated with the national establishment of sectoral targets, policies and programs that promote low-carbon development in a competitive and climate-resilient manner.

Accordingly, 35 stakeholders from different sectors of society (government, business sector, civil society) with the potential to positively influence the implementation of the NDC in the energy sector were invited to participate in a scientifically-guided dialogue to collaboratively produce knowledge relating to the current problems of the energy sector, a preferable vision and possible strategies for enabling the implementation of the National Determined Contribution (NDC). The broad affiliations of the stakeholders are given in Table 1. They were selected on the basis of both spanning broad societal groups and being known to the lead researcher (who had a climate change policy role in the Ecuadorian government) as interested and motivated towards rethinking Peruvian energy policy. We make no claim as to the representativeness of the vision and strategies that the stakeholders produced, relative to their affiliated sectors. Rather it is the power implications of (transdisciplinary) transition management processes that are our primary focus.

As said, while transdisciplinary processes ideally involve co-design in all respects from their initiation, in this case, given the political context, it was not possible to involve high-level actors from the beginning. Within the 
workshop there was nonetheless room for negotiating content, topics and for developing policy proposals in directions that reflected the views of the participants.

Regarding the selection of participants, stakeholders were selected on the basis of being oriented towards norms of sustainability and renewable energy -in government, academia, NGOs, and business. An element of snowballing was involved and the invitation was issued by the NGO WWF, in coordination with the Ministry of Environment. The financial costs incurred by WWF in this process were covered. Stakeholders known to promote natural (fossil) gas were not invited. The purpose was to provide a protected space for alternative, marginalized views of a low carbon future and the knowledge required for the foregoing was available via previous processes of engagement with the stakeholders. Regarding representativeness, the participants were not selected to represent all interests, but to compensate for marginalization and no claims are made here to representing all sections of society.

As such, the roles of the scientist (i.e. the lead authors as both analyst and practitioner) included methodological development of a participatory process, co-facilitation and epistemediator. The goal of the scientific process was to understand the feasibility of a participatory/transdisciplinary process to co-produce actionable knowledge in order to further stimulate collective action within an illiberal democratic context. The goal of practice was to articulate an alternative discourse and stimulate the creation of a supportive network for collective action towards promoting low-carbon development in the energy sector.

Table 1. Affiliations of the transdisciplinary transition arena participants

\begin{tabular}{lll}
\hline Affiliations & & Number \\
\hline State Representatives (Executive: & Energy $\quad$ and & 5 \\
Environmental Ministries) & & 2 \\
Congress Representatives & & 7 \\
Total Government & & 2 \\
Companies, Industry Chambers and $\quad$ Business & 12 \\
Associations & & 12 \\
Total Business & 4 \\
Academia and Research Institutions & 4 \\
Total Academia & 4 \\
Local NGOs and Church Representatives & 7 \\
International NGOs Representatives & 11 \\
Total NGOs & 1 \\
Bilateral Cooperation & 1 \\
Total International Organisations & 35 \\
Total Stakeholders & \\
\hline
\end{tabular}

\subsection{Process Design}

The process followed a series of phases set out below. It should be noted that participants worked in groups that were mixed across affiliations, although this may not be practical in cases where there are strong differences of opinion.

\subsubsection{Phase 1: Diagnosis of Energy System Problems}

The first phase was problem definition as perceived by the participants, informed by official government documentation (new vision and updated plans) and analytical documentation generated in other sectors of society (academia, NGOs). This described the global and national trends in which the NDC was developed and how these may require a response in future. In addition, participants were asked to consider the evolution of the implementation of the NDC in the energy sector to date; the extent to which proposals for energy strategies have been translated into public policies; what circumstances have changed since the inception of NDC and the extent to which NDC objectives and strategies are compatible with the vision of the new government. 


\subsubsection{Phase 2: Back-Casting}

The production of a common vision and strategies was undertaken in a back-casting process, whereby participants derived strategies by which to achieve the vision that they developed. These were specifically framed around the actions required to achieve the goals of the NDC in the energy sector within the current national context, including new authorities, goals, financing mechanisms, regulatory and institutional frameworks. The strategies represented the path or roadmap to follow, taking as their orientation the changes required in the elements, subsystems and dynamics, to achieve the desired restructuring of the energy system. The phase includes participatory-reflective processes, through which groups came to better understand the beliefs and interests of the stakeholders representing the different sectors of society.

The scenario process was a qualitative exercise in which participants expressed their concerns, beliefs, interests and preferences regarding a future vision of the energy system in Peru. The purpose was not to evaluate the outcome policy proposals or vision (e.g. via a multi-criteria tool). Rather, prioritization of elements was undertaken by the stakeholders through negotiation and discussion, in order to identify the key actions - in their view - required to achieve the joint vision (Roland W Scholz \& Tietje, 2002)(Roland W Scholz \& Tietje, 2002)(Wiek, Claudia, \& Scholz, 2006).

The back-casting process had the following steps:

1) Developing a common understanding of the problem (via a "world café" design), with three questions given to guide this:

a) What are the most urgent problems that should be addressed in relation to NDC-Energy in Peru?

b) What are the challenges in accelerating their viability and compliance?

c) What has changed in the current circumstances (new government) that need to be taken into account?

2) Formulating the worst scenario (two multi-sectoral groups)

3) Formulating the preferred scenario (two multi-sectoral groups)

4) Integrating two preferred scenarios in one common vision (all together)

5) Defining strategies for achieving the common vision (all together)

As stated, the aim of organising a multi-stakeholder group for interaction and dialogue was to collectively answer questions about - and respond to- the slow implementation of NDC-Energy in Peru. The process was intended to promote an environment in which conflicts and differences were managed with "preferable" rather than "perfect" solutions. It was emphasized that the objective was to create a visualization that would guide social innovation, taking into consideration issues of polarization of perceptions, and indeed deliberately seeking the exposition and confrontation of opposing reasoning and arguments. This would enable identification of the ranges of tolerance and spaces of agreement, emphasizing the creativity and experimentation of a space of reflexive governance and joint decision making (Hernández, 2014). The process thus sought to deploy a learning cycle based on the reflections of the actors on the themes, on the specific context and on the process itself (Kerr \& Tindale, 2004). The intended outcome was a group-level, shared understanding of the problems and their potential solutions (Thomas, McGarty, \& Mavor, 2009), building capacity and coalitions in the process (Galinsky, $\mathrm{Ku}$, \& Wang, 2005).

\subsubsection{Phase 3: Evaluation}

The evaluation was undertaken with ex-post questionnaires consisting of qualitative and quantitative questions relating to four evaluative dimensions (outputs, outcomes, process, and inputs) (Luederitz et al., 2016). For brevity and practicality, evaluation was undertaken with a self-appraisal approach at the end of the intervention, to support reflection and learning from the process - i.e. a process of formative evaluation. (Roland W Scholz \& Steiner, 2015b) (Walter, Helgenberger, Wiek, \& Scholz, 2007)(Chebet et al., 2018). While self-evaluation has limitations, it can still serve the purposes above and also assist with any redesign that may be required for subsequent arenas. In fact although evaluation of transdisciplinary processes is vital, the literature on this has historically been rather small (Stokols et al., 2003). One of the few (post hoc) quantitative evaluations is provided by Walter et al. (2007), who used a statistical mediation model to identify capacities developed. Miah et al. (2015) also identify a set of evaluation from the literature and provide a (nominally scaled) self-evaluation. (Vilsmaier et al., 2015) provide a qualitative evaluation of eight stakeholder engagement processes, using content analysis of interviews of participants.(Njoroge et al., 2015) develop and apply an analysis of variance-based 
assessment of the effects of the transdisciplinary process on the yield of smallholder farmers who participated in a transdisciplinary process (Roland W Scholz \& Steiner, 2015a).

The terms of the evaluation reflect the above, combined premises of transdisciplinary sustainability science research and transition management, specifically regarding the extent to which such a process supports knowledge co-production and stakeholder involvement, building transformational leadership capacities and jointly contributing to the development of policy options for energy system change. All of this is held to relate to the first stage of empowerment, namely the engendering of a belief that meaningful action is possible.

Regarding the knowledge-related ambitions of transdisciplinary sustainability science research, we are therefore also interested in to what extent the types of knowledge involved in such an arena (Brandt et al., 2013) are generated. That is, system knowledge referring to the current state of a system and the key social and other factors involved and the capacity of the system to change (Hadorn, Bradley, Pohl, Rist, \& Wiesmann, 2006); Target Knowledge referring to the more specific scope of action and problem-solving measures relating to natural constraints, social laws, norms and values within the system, as well as the interests of actors and their individual intentions (Jahn, 2008); and Transformation Knowledge referring to the practical implications that can be derived from target knowledge, in respect of changes to existing habits, practices and institutional objectives (Hadorn et al., 2006).

Moreover, we ask to what extent the arena design supports reflexivity as a part of consensus building (Popa et al., 2015)? That is, to what extent does it support critical reflection on participants' values and orientation, as well as the ability to adapt one's own positions and goals, hence supporting and enabling capacities for purposive, collective action (Patterson et al., 2017)?

Finally, we ask to what extent the arena promotes trust and long-term collaboration among the participants (individual and institutional), resulting from common understandings of the problem, the identification of a shared values and the commitment to organise joint future actions. A key element of this is hypothesised in the transdisciplinary sustainability science research literature as relating to the development of a group identity that then supports a commitment to collective action.

In this respect, (Thomas et al., 2009) refer to the psycho-social normative alignment model of promoting ongoing commitment to collective action, via the crafting of a social identity based on norms for emotion, efficacy and action that contribute to a dynamic system of meaning and hence commitment to a cause. Similarly (Reicher, Spears, \& Haslam, 2010) refer to social identity as shared and relational and as the product of a group's collective history and present. (Harris \& Lyon, 2013) observe that trust among stakeholders is shown to be built by having information on others, prior experience of working together, norms of cooperation and sanctions exerted on those who might transgress norms of behaviour (Harris \& Lyon, 2013).

In the next section we examine the performance of the arena in these terms, pursuing this further in the Discussion in relation to the implications for - and association with - the empowerment (Narayan-Parker, 2005)(Alsop, R., Bertelsen, M. F., \& Holland, 2006) and power-related issues that (Avelino \& Rotmans, 2009) identify and that are arguably often elided in transition management processes. The evaluation has two elements. First, as stated, post-hoc questionnaires with 5-point Likert-scale based response options were used for self-evaluation by participants in terms of specific aspects of empowerment as set out above: these we characterise as empowerment conditions. Second, we map the outcomes and aspects of the transdisciplinary transition management arena process to the same empowerment conditions, to show more specifically how the arena supports empowerment.

In this way we are in effect exploring the ways in which the characteristics of transdisciplinary science and transition management processes concur with - share - the characteristics of empowering conditions. We are not arguing that these are sufficient or necessary conditions across all contexts: to make a claim of this strength, we would need multiple cases representing different types of socio-political context. Table 6 and 7 presents the policy outcomes from the arena in detail.

\section{Results}

\subsection{Process Evaluation by Participants}

The performance of the TTMA was evaluated in terms of the empowerment conditions of the TTMA. That is, in terms of the perceived value of: (i) the design of Informal Arena itself; (ii) the extent to which it supported Policy Entrepreneurship; and (iii) the value of the arena as a Reflexive space. As said, performance is indicated both via quantitative (Likert) response scales, which in aggregate enable the percentage of participants expressing agreement and disagreement to be observed, and in terms of the extent and form of the vision and 
policy recommendations resulting from the arena.

Table 1 describes the evaluative terms (indicators) that the empowerment conditions are conceived of as comprising. For the design of the Informal Arena, these relate to the perceived quality of: participation, facilitation, methodology, freedom of expression, inclusiveness and information inputs. For Policy Entrepreneurship, the evaluative terms comprise: perceived concurrence with participant's expectations of transformation, aspirations, potential collective-actions, methodological suitability for aligning actors, sectoral transformative synergies and long-term cooperation capabilities. Finally, reflexive capacity of the arena was evaluated in terms of perceived: quality of the knowledge co-produced by the stakeholders in terms of relevance, ability to challenge the status quo, common understanding, clearness and rememberability, articulation of new perspectives, ability to anticipate futures and develop strategies.

Table 2. Empowerment conditions measurement indicators

\begin{tabular}{ll}
\hline $\begin{array}{l}\text { Empowerment } \\
\text { conditions }\end{array}$ & Measurement Indicator \\
\hline Informal Arena & A1. The selected participants were suitable for the participatory process \\
A2. Facilitation of the process was satisfactory. & A3. The methodology was useful for the participatory process' purposes. \\
A4. Participants were able to express their ideas and opinions freely. \\
A5. All ideas were considered in the discussion. \\
A6. The inputs presented by the speakers were useful for the discussion. \\
B1. Participants agree that the Peruvian energy system requires a sustainable \\
transformation \\
B2. Participants have common (individual or institutional) aspirations regarding \\
the future of the energy system in Peru \\
B3. Participants have the potential to articulate joint actions for supporting a \\
transformation \\
B4. The participatory process' methodology was suitable for promoting the \\
articulation of actors. \\
B5. Active participation of all sectors is needed for the success of the \\
implementation of transformation strategies \\
B6. The appropriate level of inter-institutional involvement is a joint long-term \\
cooperation strategy
\end{tabular}




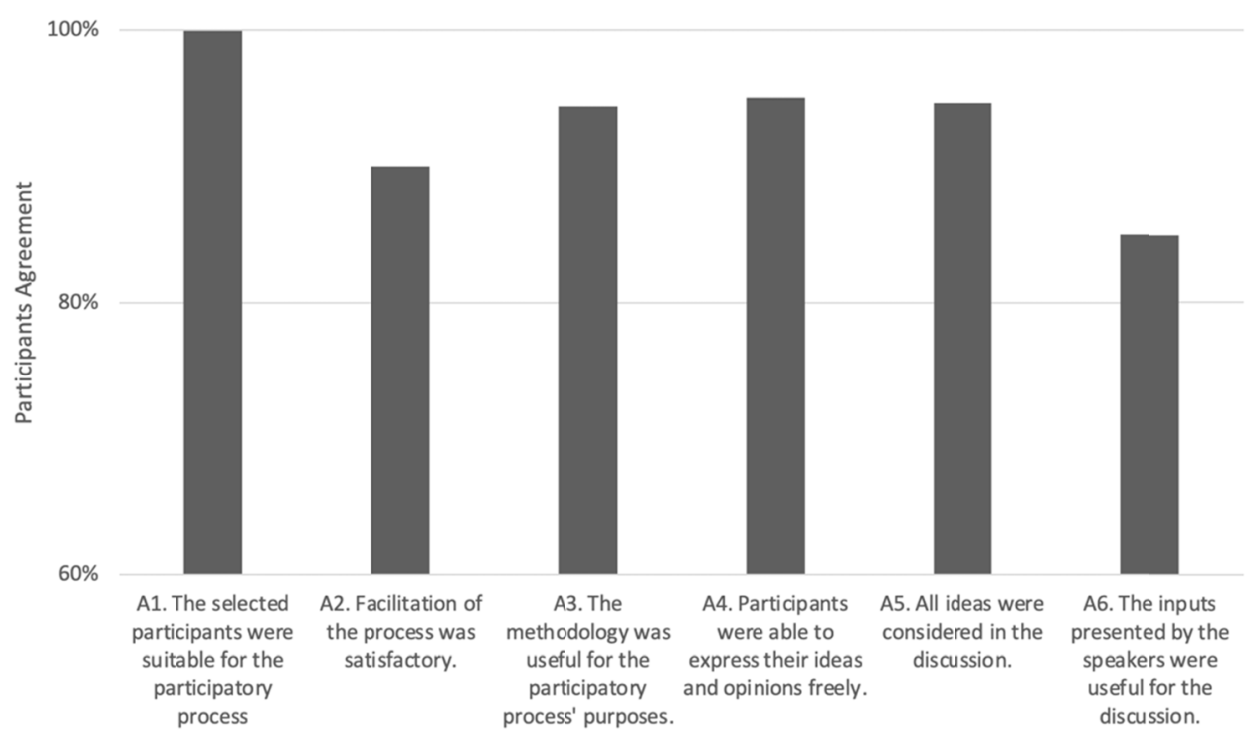

Figure 3. Perceptions of the informal arena design

Figure 3 describes participant satisfaction with the arena design. The percentages relate to the participants as a whole and to their agreement with the statements A1, A2, A3, A4, A5, A6 in Table 1. Overall, participants agreed that the Informal Arena design was effective in terms of the range of participants, facilitation, methodology for exploring alternative energy policy, freedom of expression, inclusiveness and information input.

Table 3 shows the connections between the measurement indicators as applied to the Informal Arena design, with the concept of empowerment according to (Narayan-Parker, 2005), where the creation of an opportunity structure that influences institutional climate and social and political structures is vital for the empowerment of a community of actors acting as a protected space. Additionally, as (Alsop, R., Bertelsen, M. F., \& Holland, 2006) emphasise, the opportunity structure conceptually connects, via empowerment, the local/professional community level with an intermediary level of agency.

Table 3. Linkages between informal arena process indicators and empowerment

\begin{tabular}{|c|c|c|c|c|c|c|}
\hline Measurement Indicator & $\begin{array}{c}\text { Opportunity } \\
\text { Structure: } \\
\text { Institutional } \\
\text { Climate }\end{array}$ & $\begin{array}{c}\text { Opportunity } \\
\text { Structure: } \\
\text { Social and } \\
\text { Political } \\
\text { Structure }\end{array}$ & $\begin{array}{l}\text { Agency: } \\
\text { Individual } \\
\text { Assets and } \\
\text { Capabilities }\end{array}$ & $\begin{array}{l}\text { Agency: } \\
\text { Collective Assets } \\
\text { and Capabilities }\end{array}$ & Outcomes & $\begin{array}{c}\text { Level of } \\
\text { empowerment }\end{array}$ \\
\hline $\begin{array}{c}\text { A1. The selected } \\
\text { participants were suitable } \\
\text { for the participatory } \\
\text { process }\end{array}$ & $\begin{array}{l}\text { Marginalized } \\
\text { actors were } \\
\text { included in the } \\
\text { participatory } \\
\text { process }\end{array}$ & $\begin{array}{c}\text { Space of } \\
\text { interaction was } \\
\text { specifically for a } \\
\text { group of } \\
\text { liked-minded } \\
\text { marginalized } \\
\text { actors }\end{array}$ & $\begin{array}{c}\text { Participants were } \\
\text { able to be } \\
\text { proactive and } \\
\text { open to others' } \\
\text { perspectives }\end{array}$ & $\begin{array}{c}\text { Participants } \\
\text { represented all } \\
\text { sectors of society: } \\
\text { State, Civil } \\
\text { Society, } \\
\text { Academia and } \\
\text { Business Sectors }\end{array}$ & $\begin{array}{c}\text { Professional } \\
\text { community } \\
\text { development } \\
\text { acting as a } \\
\text { protected space }\end{array}$ & $\begin{array}{l}\text { Local level / } \\
\text { Intermediary } \\
\text { level }\end{array}$ \\
\hline $\begin{array}{l}\text { A2. Facilitation of the } \\
\text { process was satisfactory. }\end{array}$ & $\begin{array}{c}\text { Participants } \\
\text { demonstrated } \\
\text { local } \\
\text { organizational } \\
\text { capacity }\end{array}$ & $\begin{array}{c}\text { Facilitation } \\
\text { mitigated } \\
\text { competition and } \\
\text { conflict }\end{array}$ & $\begin{array}{l}\text { Facilitation } \\
\text { understood the } \\
\text { political power } \\
\text { relations in } \\
\text { advanced }\end{array}$ & $\begin{array}{c}\text { Participatory } \\
\text { process was } \\
\text { effectively } \\
\text { self-organized by } \\
\text { participants based } \\
\text { on agreed rules }\end{array}$ & $\begin{array}{c}\text { Professional } \\
\text { community } \\
\text { development } \\
\text { acting as a } \\
\text { protected space }\end{array}$ & Local level \\
\hline
\end{tabular}




\begin{tabular}{|c|c|c|c|c|c|c|}
\hline $\begin{array}{l}\text { A3. The methodology was } \\
\text { useful for the participatory } \\
\text { process' purposes. }\end{array}$ & $\begin{array}{c}\text { Participants } \\
\text { demonstrated } \\
\text { local } \\
\text { organizational } \\
\text { capacity }\end{array}$ & $\begin{array}{c}\text { Methodology } \\
\text { mitigated } \\
\text { competition and } \\
\text { conflict }\end{array}$ & $\begin{array}{l}\text { Methodology was } \\
\text { adapted to the } \\
\text { local context } \\
\text { considering } \\
\text { political power } \\
\text { relations among } \\
\text { participants }\end{array}$ & $\begin{array}{c}\text { Participatory } \\
\text { process was } \\
\text { effectively } \\
\text { self-organized by } \\
\text { participants based } \\
\text { on agreed rules }\end{array}$ & $\begin{array}{c}\text { Professional } \\
\text { community } \\
\text { development } \\
\text { acting as a } \\
\text { protected space }\end{array}$ & Local level \\
\hline $\begin{array}{l}\text { A4. Participants were able } \\
\text { to express their ideas and } \\
\text { opinions freely. }\end{array}$ & $\begin{array}{l}\text { All ideas were } \\
\text { considering } \\
\text { when } \\
\text { co-producing } \\
\text { knowledge }\end{array}$ & $\begin{array}{c}\text { Space of } \\
\text { interaction was } \\
\text { democratic and } \\
\text { open }\end{array}$ & $\begin{array}{l}\text { Participants } \\
\text { trusted the others } \\
\text { within the space } \\
\text { of interaction }\end{array}$ & $\begin{array}{l}\text { All participants } \\
\text { had a voice }\end{array}$ & $\begin{array}{c}\text { Professional } \\
\text { community } \\
\text { development } \\
\text { acting as a } \\
\text { protected space }\end{array}$ & Local level \\
\hline $\begin{array}{l}\text { A5. All ideas were } \\
\text { considered in the } \\
\text { discussion. }\end{array}$ & $\begin{array}{l}\text { All ideas were } \\
\text { considering } \\
\text { when } \\
\text { co-producing } \\
\text { knowledge }\end{array}$ & $\begin{array}{c}\text { Space of } \\
\text { interaction was } \\
\text { democratic and } \\
\text { open }\end{array}$ & $\begin{array}{l}\text { Participants } \\
\text { trusted the others } \\
\text { within the space } \\
\text { of interaction }\end{array}$ & $\begin{array}{c}\text { All participants } \\
\text { had a voice }\end{array}$ & $\begin{array}{c}\text { Professional } \\
\text { community } \\
\text { development } \\
\text { acting as a } \\
\text { protected space }\end{array}$ & Local level \\
\hline $\begin{array}{l}\text { A6. The inputs presented } \\
\text { by the speakers were } \\
\text { useful for the discussion. }\end{array}$ & $\begin{array}{c}\text { Access to } \\
\text { information was } \\
\text { provided to all } \\
\text { participants }\end{array}$ & $\mathrm{n} / \mathrm{a}$ & $\begin{array}{l}\text { Experts where } \\
\text { invited to share } \\
\text { their knowledge }\end{array}$ & $\mathrm{n} / \mathrm{a}$ & $\begin{array}{c}\text { Professional } \\
\text { community } \\
\text { development } \\
\text { acting as a } \\
\text { protected space }\end{array}$ & $\begin{array}{c}\text { Local level / } \\
\text { Intermediary } \\
\text { level }\end{array}$ \\
\hline
\end{tabular}

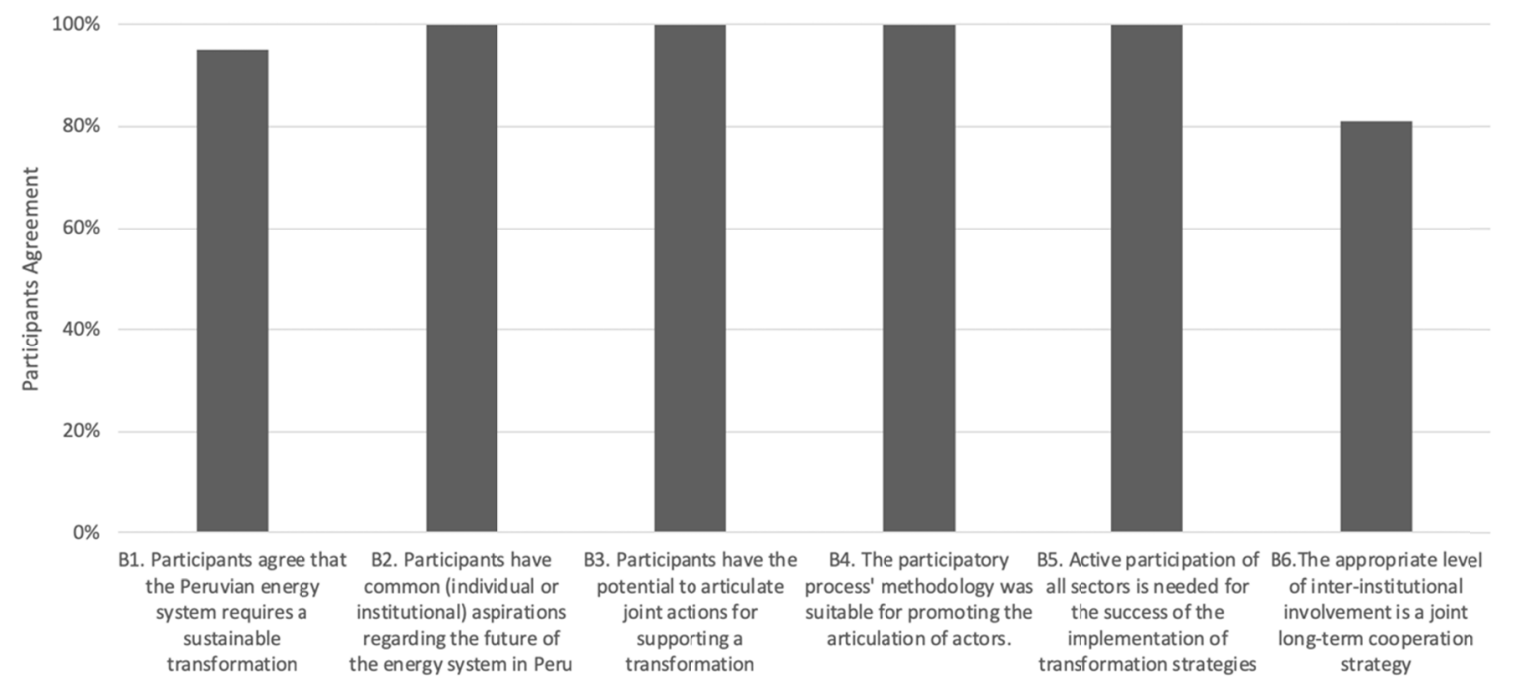

Figure 4. Perceptions of the extent to which the arena supports Policy Entrepreneurship

Figure 4 reports participants' perceptions of the TTMA as supporting policy entrepreneurship (statements B1, B2, B3, B4, B5, B6). Overall, participants agreed that the arena supported the generation of common understanding about transformation, common aspirations, potential for collective action, the articulation of actors, interdependencies of sectors and the development of a long-term inter-institutional cooperation strategy.

Table 4 shows the linkages between the indicators of the Policy Entrepreneurship and empowerment (Narayan-Parker, 2005), where policy entrepreneurship is defined as the existence of an opportunity structure for influencing institutional and political structures, in combination with individual and collective assets and capabilities, resulting in entrepreneurial agency n (Alsop, R., Bertelsen, M. F., \& Holland, 2006). Thus defined, Policy Entrepreneurship is conceived of as enabling synergies across structures and agency dynamizing intermediation between local and state level of intervention (ibid). 
Table 4. Linkages between policy entrepreneurship indicators and empowerment

\begin{tabular}{|c|c|c|c|c|c|c|}
\hline $\begin{array}{c}\text { Measurement } \\
\text { Indicator }\end{array}$ & $\begin{array}{l}\text { Opportunity } \\
\text { Structure: } \\
\text { Institutional } \\
\text { Climate }\end{array}$ & $\begin{array}{c}\text { Opportunity } \\
\text { Structure: Social } \\
\text { and Political } \\
\text { Structure }\end{array}$ & $\begin{array}{c}\text { Agency: } \\
\text { Individual } \\
\text { Assets and } \\
\text { Capabilities }\end{array}$ & $\begin{array}{l}\text { Agency: } \\
\text { Collective Assets } \\
\text { and Capabilities }\end{array}$ & Outcomes & $\begin{array}{c}\text { Level of } \\
\text { empowerment }\end{array}$ \\
\hline $\begin{array}{l}\text { B1. Participants agree } \\
\text { that the Peruvian } \\
\text { energy system } \\
\text { requires a sustainable } \\
\text { transformation }\end{array}$ & $\begin{array}{l}\text { Access to } \\
\text { information was } \\
\text { provided to all } \\
\text { participants }\end{array}$ & $\begin{array}{l}\text { Marginalized actors } \\
\text { supporting } \\
\text { sustainability were } \\
\text { articulated to build } \\
\text { alternative } \\
\text { discourse }\end{array}$ & $\begin{array}{l}\text { Participants were } \\
\text { experienced } \\
\text { professionals } \\
\text { from the energy } \\
\text { sector from } \\
\text { different } \\
\text { organizations }\end{array}$ & $\begin{array}{l}\text { Participants build } \\
\text { an identity based } \\
\text { on shared values, } \\
\text { beliefs and } \\
\text { interests. }\end{array}$ & $\begin{array}{l}\text { Network and } \\
\text { coalition } \\
\text { building for } \\
\text { collective } \\
\text { action }\end{array}$ & $\begin{array}{l}\text { Intermediary } \\
\text { level }\end{array}$ \\
\hline $\begin{array}{l}\text { B2. Participants have } \\
\text { common (individual } \\
\text { or institutional) } \\
\text { aspirations regarding } \\
\text { the future of the } \\
\text { energy system in Peru }\end{array}$ & $\mathrm{n} / \mathrm{a}$ & $\begin{array}{l}\text { Articulation of } \\
\text { actors stimulate the } \\
\text { creation of an } \\
\text { informal institution } \\
\text { that represents a } \\
\text { common vision of a } \\
\text { professional } \\
\text { community }\end{array}$ & $\begin{array}{l}\text { Participants have } \\
\text { individual values, } \\
\text { beliefs and } \\
\text { interests }\end{array}$ & $\begin{array}{l}\text { Participants build a } \\
\text { group identity } \\
\text { based on shared } \\
\text { values, beliefs and } \\
\text { interests. }\end{array}$ & $\begin{array}{l}\text { Network and } \\
\text { coalition } \\
\text { building for } \\
\text { collective } \\
\text { action }\end{array}$ & $\begin{array}{l}\text { Intermediary } \\
\text { level / State } \\
\text { Level }\end{array}$ \\
\hline $\begin{array}{l}\text { B3. Participants have } \\
\text { the potential to } \\
\text { articulate joint actions } \\
\text { for supporting a } \\
\text { transformation }\end{array}$ & $\begin{array}{l}\text { New information } \\
\text { and knowledge was } \\
\text { developed within } \\
\text { the participatory } \\
\text { process }\end{array}$ & $\begin{array}{l}\text { Articulated } \\
\text { participants } \\
\text { increased their } \\
\text { negotiations power } \\
\text { in order to } \\
\text { influence change }\end{array}$ & $\begin{array}{l}\text { Stakeholders } \\
\text { have the human } \\
\text { and material } \\
\text { resources to } \\
\text { promote a } \\
\text { long-term } \\
\text { cooperation }\end{array}$ & $\begin{array}{l}\text { Actor constellation } \\
\text { developed a } \\
\text { common voice, } \\
\text { organizational } \\
\text { structure, a group } \\
\text { representation and } \\
\text { identity }\end{array}$ & $\begin{array}{l}\text { Network and } \\
\text { coalition } \\
\text { building for } \\
\text { collective } \\
\text { action }\end{array}$ & $\begin{array}{l}\text { Intermediary } \\
\text { level / State } \\
\text { Level }\end{array}$ \\
\hline $\begin{array}{l}\text { B4. The participatory } \\
\text { process' methodology } \\
\text { was suitable for } \\
\text { promoting the } \\
\text { articulation of actors. }\end{array}$ & $\begin{array}{l}\text { Participants were } \\
\text { able to interact, } \\
\text { dialogue and unify } \\
\text { positions }\end{array}$ & $\begin{array}{l}\text { Agreements were } \\
\text { built on common } \\
\text { interests }\end{array}$ & $\mathrm{n} / \mathrm{a}$ & $\begin{array}{l}\text { Participants build a } \\
\text { group identity } \\
\text { based on shared } \\
\text { values, beliefs and } \\
\text { interests. }\end{array}$ & $\begin{array}{l}\text { Network and } \\
\text { coalition } \\
\text { building for } \\
\text { collective } \\
\text { action }\end{array}$ & $\begin{array}{l}\text { Intermediary } \\
\text { level }\end{array}$ \\
\hline $\begin{array}{l}\text { B5. Active } \\
\text { participation of all } \\
\text { sectors is needed for } \\
\text { the success of the } \\
\text { implementation of } \\
\text { transformation } \\
\text { strategies }\end{array}$ & $\begin{array}{l}\text { Participants were } \\
\text { able to interact, } \\
\text { dialogue and unify } \\
\text { positions }\end{array}$ & $\begin{array}{l}\text { Articulation of } \\
\text { actors stimulate the } \\
\text { creation of an } \\
\text { informal institution } \\
\text { that represents a } \\
\text { common vision of a } \\
\text { professional } \\
\text { community }\end{array}$ & $\begin{array}{l}\text { Participants were } \\
\text { able to be } \\
\text { proactive and } \\
\text { open to others' } \\
\text { perspectives }\end{array}$ & $\begin{array}{l}\text { Participants } \\
\text { represented all } \\
\text { sectors of society: } \\
\text { State, Civil } \\
\text { Society, Academia } \\
\text { and Business } \\
\text { Sectors }\end{array}$ & $\begin{array}{l}\text { Network and } \\
\text { coalition } \\
\text { building for } \\
\text { collective } \\
\text { action }\end{array}$ & $\begin{array}{l}\text { Intermediary } \\
\text { level / State } \\
\text { Level }\end{array}$ \\
\hline $\begin{array}{l}\text { B6. The appropriate } \\
\text { level of } \\
\text { inter-institutional } \\
\text { involvement is a joint } \\
\text { long-term cooperation } \\
\text { strategy }\end{array}$ & $\begin{array}{l}\text { Stakeholders are } \\
\text { self-accountable for } \\
\text { a joint long-term } \\
\text { cooperation } \\
\text { strategy }\end{array}$ & $\begin{array}{l}\text { Actor constellation } \\
\text { provides structure } \\
\text { and purpose } \\
\text { towards external } \\
\text { competition and } \\
\text { conflict readiness }\end{array}$ & $\begin{array}{l}\text { Stakeholders } \\
\text { have the human } \\
\text { and material } \\
\text { resources to } \\
\text { promote a } \\
\text { long-term } \\
\text { cooperation }\end{array}$ & $\begin{array}{l}\text { Actor constellation } \\
\text { developed a } \\
\text { common voice, } \\
\text { organizational } \\
\text { structure, a group } \\
\text { representation and } \\
\text { identity }\end{array}$ & $\begin{array}{l}\text { Network and } \\
\text { coalition } \\
\text { building for } \\
\text { collective } \\
\text { action }\end{array}$ & $\begin{array}{l}\text { Intermediary } \\
\text { level / State } \\
\text { Level }\end{array}$ \\
\hline
\end{tabular}

Figure 5 reports participants' perceptions of the TTMA as relating to the processes of knowledge co-production/reflexivity. Overall, participants agreed that with statements $\mathrm{C} 1, \mathrm{C} 2, \mathrm{C} 3, \mathrm{C} 4, \mathrm{C} 5, \mathrm{C} 6$, namely that the process of reflexivity resulted in a high quality of knowledge in terms of the following criteria: relevance to the current circumstances, challenging status quo, understanding of the processes of transformation, clear and rememberable, articulation of perspectives and developing of future scenarios and strategies. 


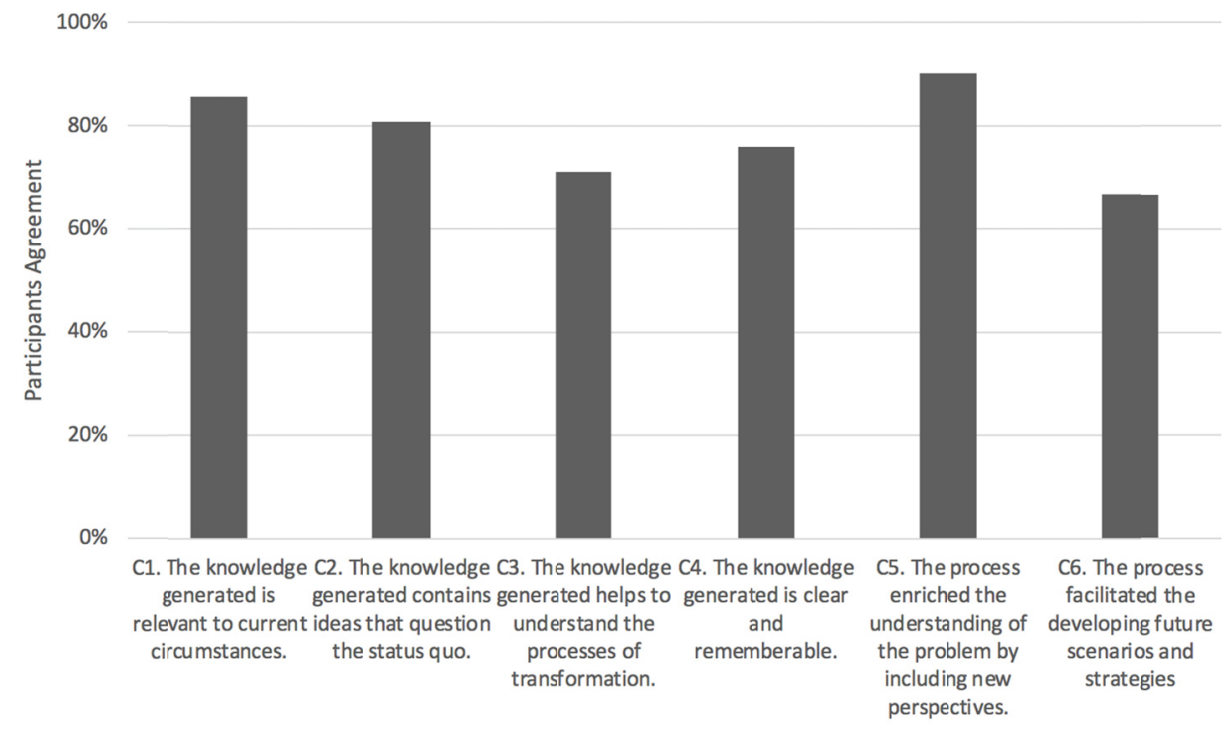

Figure 5. Perceptions of reflexivity

Table 5 shows the linkages between indicators of Reflexivity and empowerment (Narayan-Parker, 2005), whereby a process of the co-production of knowledge within a transdisciplinary space boosts individual and collective assets and capabilities and stimulates collective action, by articulating a shared alternative discourse that has the potential to be introduced at the level of national politics (Alsop, R., Bertelsen, M. F., \& Holland, 2006).

Table 5. Linkages between reflexivity indicators and empowerment

\begin{tabular}{|c|c|c|c|c|c|c|}
\hline $\begin{array}{c}\text { Measurement } \\
\text { Indicator }\end{array}$ & $\begin{array}{l}\text { Opportunity } \\
\text { Structure: } \\
\text { Institutional } \\
\text { Climate }\end{array}$ & $\begin{array}{c}\text { Opportunity } \\
\text { Structure: Social } \\
\text { and Political } \\
\text { Structure }\end{array}$ & $\begin{array}{c}\text { Agency: } \\
\text { Individual Assets } \\
\text { and Capabilities }\end{array}$ & $\begin{array}{l}\text { Agency: } \\
\text { Collective } \\
\text { Assets and } \\
\text { Capabilities }\end{array}$ & Outcomes & $\begin{array}{c}\text { Level of } \\
\text { empowerment }\end{array}$ \\
\hline $\begin{array}{l}\text { C1. The knowledge } \\
\text { generated is } \\
\text { relevant to current } \\
\text { circumstances. }\end{array}$ & $\begin{array}{l}\text { Actionable } \\
\text { knowledge was } \\
\text { co-produced } \\
\text { within the } \\
\text { participatory } \\
\text { process }\end{array}$ & $\begin{array}{l}\text { Process promoted } \\
\text { socio-political } \\
\text { activism based on a } \\
\text { common } \\
\text { understanding of } \\
\text { the problem }\end{array}$ & $\begin{array}{l}\text { Participants } \\
\text { contributed with } \\
\text { ideas and } \\
\text { perspectives to } \\
\text { the collective } \\
\text { production of } \\
\text { actionable } \\
\text { knowledge }\end{array}$ & $\begin{array}{l}\text { Common } \\
\text { alternative } \\
\text { discourse about } \\
\text { the future of the } \\
\text { energy system } \\
\text { was co-produced }\end{array}$ & $\begin{array}{l}\text { Actionable } \\
\text { knowledge } \\
\text { co-production } \\
\text { encompassing } \\
\text { common } \\
\text { understanding of the } \\
\text { problem, common } \\
\text { vision and strategies }\end{array}$ & Local level \\
\hline $\begin{array}{l}\text { C2. The knowledge } \\
\text { generated contains } \\
\text { ideas that question } \\
\text { the status quo. }\end{array}$ & $\begin{array}{l}\text { Actionable } \\
\text { knowledge was } \\
\text { co-produced } \\
\text { within the } \\
\text { participatory } \\
\text { process }\end{array}$ & $\begin{array}{l}\text { Process promoted } \\
\text { socio-political } \\
\text { activism based on a } \\
\text { common } \\
\text { understanding of } \\
\text { the problem }\end{array}$ & $\begin{array}{l}\text { Participants } \\
\text { contributed with } \\
\text { ideas and } \\
\text { perspectives to } \\
\text { the collective } \\
\text { production of } \\
\text { actionable } \\
\text { knowledge }\end{array}$ & $\begin{array}{l}\text { Common } \\
\text { alternative } \\
\text { discourse about } \\
\text { the future of the } \\
\text { energy system } \\
\text { was co-produced }\end{array}$ & $\begin{array}{l}\text { Actionable } \\
\text { knowledge } \\
\text { co-production } \\
\text { encompassing } \\
\text { common } \\
\text { understanding of the } \\
\text { problem, common } \\
\text { vision and strategies }\end{array}$ & $\begin{array}{l}\text { Local level } \\
\text { Intermediary } \\
\text { level }\end{array}$ \\
\hline
\end{tabular}




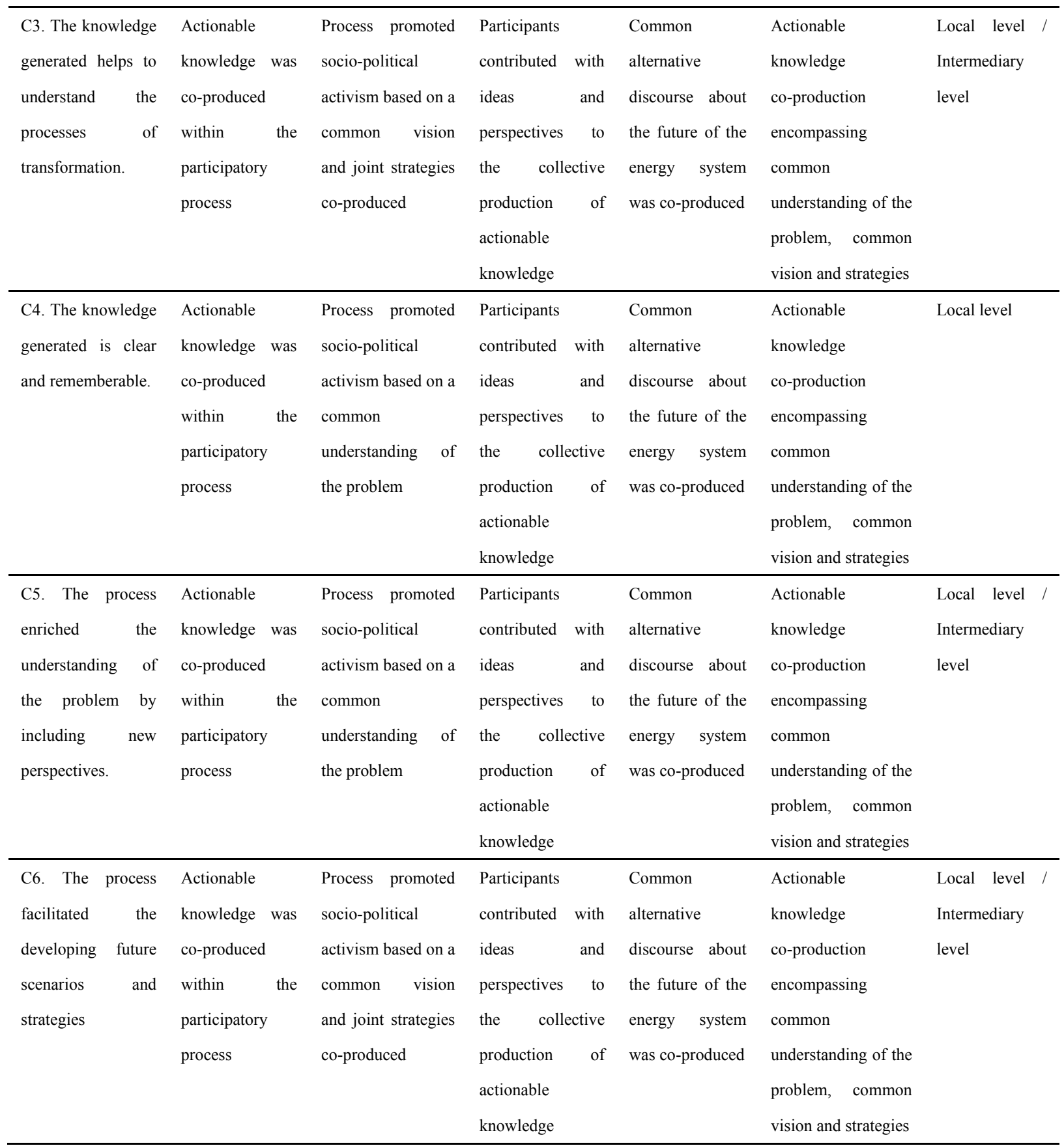

Tables 6 and 7 summarize the substantive outcomes from the group in terms of strategic objectives and visions, as based on a recording via silent observers, who transcribed the dialogue of the forum process. The strategic objectives are mainly related to the need for: (a) networks for collaborative planning (planning governance); (b) financial mechanisms for investments and incentivizing the renewable energy sector; (c) collaborative knowledge production regarding regulatory frameworks; (d) the transparency of official information; (e) communication, education and training. The common vision emphasizes: (a) the decentralization and cross-sectoral participation in the planning and decision-making processes of the energy system (participatory governance); (b) high penetration of distributed generation based on solar, wind, biomass and geothermal (non-conventional renewable energies); and (c) a fundamental cultural change that enables continues learning and transformation.

The system and target knowledge generated by the stakeholders described participants' perception of the energy system problems as they are now, followed by a preferable scenario comprising eight different components: interaction of the energy plan with the national developmental plan, energy planning processes and principles, 
enabling environments (financial mechanisms, knowledge transfer and capacity building), technology and infrastructure of the energy matrix, regulatory frameworks, institutional frameworks, agendas intersections, cultural and mindset change.

Additionally, transformation knowledge was generated regarding possible strategies for achieving the preferable scenario, categorized here in terms of nine types: Cross-sectoral collaborative energy planning, Educational Strategies for Sustainable Development, Financial mechanisms for sustainable development, Information transparency and accountability initiative, Institutional and professional capacities building programs, Knowledge Co-production Platforms, Regulatory framework development, Strategic Environmental Communication Campaign, Supportive Networks Articulation. The propositions were developed by the stakeholders within the session. They were categorized and organized in the session guided by the facilitation. The final propositions were circulated to the stakeholders after the meeting. The propositions served to develop a letter with policy recommendations directed to the ministry of energy and signed by the whole group. The group continued to network with each other actively after the meeting and created communication channels among the participants.

Table 6. Enabling NDC Strategic Objectives proposed by the transdisciplinary transition management arena for Peru

\begin{tabular}{|c|c|}
\hline Category & Strategic Objectives \\
\hline \multirow{5}{*}{$\begin{array}{l}\text { Cross-sectoral collaborative energy } \\
\text { planning }\end{array}$} & $\begin{array}{l}\text { To consider renewable energy as a future export product linked to the productive matrix transformation } \\
\text { under the National Development Plan }\end{array}$ \\
\hline & To create learning spaces for participatory planning among stakeholders in order to have a common goal \\
\hline & To create spaces for negotiation and dialogue among stakeholders in order to have a common vision \\
\hline & $\begin{array}{l}\text { To promote the electrification of the economy based on renewable energies as a National Strategy for } \\
\text { Sustainability }\end{array}$ \\
\hline & $\begin{array}{l}\text { To enable the implementation of international commitments, cooperation and funding strategies developed } \\
\text { for the Conference of the Parties } 20 \text { in Lima }\end{array}$ \\
\hline $\begin{array}{l}\text { Educational Strategies for Sustainable } \\
\text { Development }\end{array}$ & To develop training courses for schools and universities \\
\hline \multirow{4}{*}{$\begin{array}{l}\text { Financial mechanisms for sustainable } \\
\text { development }\end{array}$} & $\begin{array}{l}\text { To design and implement investment protection mechanisms in accordance to the development of renewable } \\
\text { energy institutional and regulatory frameworks }\end{array}$ \\
\hline & To attract more private international and national investors \\
\hline & To incentivize renewables investments and divest oil \& gas \\
\hline & To incentivize private investing in renewable energy infrastructure \\
\hline \multirow{2}{*}{$\begin{array}{l}\text { Information transparency } \\
\text { accountability initiative }\end{array}$} & To design and implement an information transparency and accountability initiatives for the energy sector \\
\hline & $\begin{array}{l}\text { To review Natural Gas exploitation and export contracts with operators and intermediaries in order to } \\
\text { increase profit for the state and society }\end{array}$ \\
\hline \multirow{2}{*}{$\begin{array}{l}\text { Institutional and professional } \\
\text { capacities building programs }\end{array}$} & $\begin{array}{l}\text { To strengthen institutional and professional capacities regarding analysis, design and implementation of } \\
\text { Energy Sustainability, Renewable Energy and Energy Efficiency projects }\end{array}$ \\
\hline & To design and implement professional capacity building and training programs about renewable energy \\
\hline \multirow{6}{*}{ Knowledge Co-production Platforms } & To empower civil society by creating knowledge co-production and dialogue spaces \\
\hline & $\begin{array}{l}\text { To create knowledge production and transfer platforms (Think Tanks, Platforms, Dialogues, Fora, Research } \\
\text { Centres) }\end{array}$ \\
\hline & $\begin{array}{l}\text { To create think tanks and state-sponsored research centres to support energy planning and produce } \\
\text { knowledge about renewable energies }\end{array}$ \\
\hline & $\begin{array}{l}\text { To support private technological innovation based on the development of star-ups, spin-offs and } \\
\text { entrepreneurial initiatives }\end{array}$ \\
\hline & $\begin{array}{l}\text { To create awareness of the relevance of Renewable Energy use in the civil society through knowledge } \\
\text { co-production and empowerment }\end{array}$ \\
\hline & $\begin{array}{l}\text { To design and implement alternative discourses to be appropriate by political organizations supporting } \\
\text { sustainability }\end{array}$ \\
\hline
\end{tabular}


To design and implement regulatory frameworks for the deployment of distributed generation at local governmental levels

To design and implement regulatory frameworks in order to ensure the participation of renewable energy companies in the free and regulated market

To design and implement regulatory frameworks to stimulate public-private partnerships

To eliminate fossil-related incentives and promote transparent competition and access for renewable technologies

Regulatory framework development

\begin{tabular}{l}
\hline To design and implement carbon taxes / pricing mechanisms \\
\hline To ensure participation of several actors via different mechanisms to invest on renewable energy projects \\
\hline To institutionalize revision and up-to-date mechanisms of the legal framework in order to improve the \\
institutional framework and alignment of actors: government, private sector, customer \\
\hline To design and implement regulatory frameworks in order to decentralize energy systems and provide market \\
access and private-public partnerships \\
\hline To design and implement regulatory frameworks to ensure financial mechanisms for the subnational levels \\
To design and implement massive Sustainability and Renewable Energy communication campaigns \\
\hline To design and implement massive sustainable consumption communication campaigns \\
To organize and institutionalize cross-sectoral dialogues in order to co-produce knowledge, articulate \\
stakeholders and generate robust alternative discourses
\end{tabular}

Table 7. Perceived energy system problems and visions

\begin{tabular}{|c|c|c|c|}
\hline Categories & Sub-categories & Problem & Vision \\
\hline \multirow{4}{*}{ Planning } & $\begin{array}{l}\text { National Development } \\
\text { Plan }\end{array}$ & $\begin{array}{l}\text { National developmental plan is not connected to } \\
\text { energy planning }\end{array}$ & $\begin{array}{l}\text { To export renewable energy to neighbour } \\
\text { countries based on enormous local potential }\end{array}$ \\
\hline & $\begin{array}{l}\text { Planning Goal / } \\
\text { Horizon }\end{array}$ & Lack of long term goals & $\begin{array}{l}\text { To have a common long-term goal about energy } \\
\text { future }\end{array}$ \\
\hline & Renewability & Electricity sector dependence on natural gas \& oil & $\begin{array}{l}\text { Electricity generated from } 100 \% \text { renewable } \\
\text { energies (solar, wind, biomass, geothermal) for } \\
\text { the } 100 \% \text { of Peruvians by } 2040\end{array}$ \\
\hline & Energy Planning & Lack of consensus about an energy future & To have a common vision about energy future \\
\hline \multirow{4}{*}{ Governance } & $\begin{array}{l}\text { Subnational level } \\
\text { participation }\end{array}$ & Lack of Local Government Participation & $\begin{array}{l}\text { Participation of local governments in decision } \\
\text { making - decentralization of decision-making }\end{array}$ \\
\hline & $\begin{array}{ll}\text { Private } & \text { sector } \\
\text { participation } & \end{array}$ & $\begin{array}{l}\text { Renewable energy companies cannot participate in } \\
\text { the free and regulated market }\end{array}$ & $\begin{array}{l}\text { Renewable energy companies are encouraged } \\
\text { participate in the free and regulated market }\end{array}$ \\
\hline & $\begin{array}{l}\text { Cross-sectoral } \\
\text { partnerships }\end{array}$ & Lack of cross-sectoral partnerships & $\begin{array}{l}\text { Existence of articulated supportive networks for } \\
\text { the development of the renewable energy sector }\end{array}$ \\
\hline & $\begin{array}{l}\text { Civil Society } \\
\text { Empowerment }\end{array}$ & $\begin{array}{l}\text { Lack of participation of civil society in } \\
\text { decision-making }\end{array}$ & $\begin{array}{l}\text { Participatory and democratic energy governance } \\
\text { systems }\end{array}$ \\
\hline \multirow{5}{*}{$\begin{array}{l}\text { Regulatory } \\
\text { Frameworks }\end{array}$} & \multirow{3}{*}{$\begin{array}{l}\text { Incentives } \\
\text { Disincentives }\end{array}$} & Inappropriate incentives directed to fossil fuels & $\begin{array}{l}\text { Barriers to renewable energy projects deployment } \\
\text { are eliminated }\end{array}$ \\
\hline & & No Carbon Taxes & $\begin{array}{l}\text { Carbon Taxes are working and supporting the } \\
\text { low-carbon development strategies }\end{array}$ \\
\hline & & $\begin{array}{l}\text { Lack of auctions for renewable electricity } \\
\text { procurement }\end{array}$ & $\begin{array}{l}\text { Several mechanisms to encourage the } \\
\text { participation of new providers of energy }\end{array}$ \\
\hline & Access to the Market & No change or deterioration of legal framework & $\begin{array}{l}\text { Dynamic and smart processes of continues } \\
\text { revision and improvement of legal frameworks } \\
\text { are implemented }\end{array}$ \\
\hline & Energy Prices / Tariffs & $\begin{array}{l}\text { No clear energy prices and tariffs - externalities are } \\
\text { no consider in the prices and tariffs }\end{array}$ & $\begin{array}{l}\text { Energy information about costs, prices and tariffs } \\
\text { are transparent and accessible to the publics }\end{array}$ \\
\hline
\end{tabular}




\begin{tabular}{|c|c|c|c|}
\hline \multirow{3}{*}{$\begin{array}{l}\text { Institutional } \\
\text { Framework }\end{array}$} & $\begin{array}{l}\text { Degree } \\
\text { centralisation }\end{array}$ & Centralized national system & Sub-national decentralised systems \\
\hline & Sectoral Structure & Investment-inhibiting political framework & $\begin{array}{l}\text { Political framework that fosters investments and } \\
\text { international cooperation }\end{array}$ \\
\hline & Informal Networks & Lack of dialogue processes among stakeholders & $\begin{array}{l}\text { Stakeholders participate in dialogue platforms in } \\
\text { order to support the innovation of the energy } \\
\text { sector }\end{array}$ \\
\hline \multirow{7}{*}{$\begin{array}{l}\text { Enabling } \\
\text { environments }\end{array}$} & \multirow{4}{*}{ Financial Mechanisms } & Lack of financial mechanisms & Budget for decentralised sub-national systems \\
\hline & & Lack of international investment & Increase direct international investments \\
\hline & & $\begin{array}{l}\text { Investments are directed towards new oil and gas } \\
\text { reserves exploration }\end{array}$ & $\begin{array}{l}\text { Investments are redirected towards renewable } \\
\text { energy sources exploration }\end{array}$ \\
\hline & & Lack of financial mechanisms & $\begin{array}{l}\text { Political framework that fosters investments and } \\
\text { international cooperation }\end{array}$ \\
\hline & \multirow{2}{*}{$\begin{array}{l}\text { Knowledge } \\
\text { Production and } \\
\text { technology transfer }\end{array}$} & Lack of Knowledge regarding Renewable energy & $\begin{array}{l}\text { Knowledge platforms and think tanks foster } \\
\text { learning loops about renewable energy and } \\
\text { stimulate sectoral innovation }\end{array}$ \\
\hline & & $\begin{array}{l}\text { Lack of knowledge regarding renewable energy } \\
\text { technologies }-100 \% \text { technological dependence } \\
\text { from foreign countries }\end{array}$ & $\begin{array}{l}\text { Peruvian firms develop and provide renewable } \\
\text { energy technologies }\end{array}$ \\
\hline & Capacity building & $\begin{array}{l}\text { Lack of capacities concerning Sustainability, } \\
\text { Renewable Energy and Energy Efficiency }\end{array}$ & $\begin{array}{l}\text { Widespread knowhow about Sustainability, } \\
\text { Renewable Energy and Energy Efficiency }\end{array}$ \\
\hline \multirow{5}{*}{$\begin{array}{l}\text { Cultural } \\
\text { Change }\end{array}$} & Education & $\begin{array}{l}\text { Lack of education concerning Sustainability and } \\
\text { Renewable Energy }\end{array}$ & $\begin{array}{l}\text { Widespread knowledge about Sustainability and } \\
\text { Renewable Energy }\end{array}$ \\
\hline & \multirow{3}{*}{ Mind-set change } & $\begin{array}{l}\text { No political willingness to foster the development of } \\
\text { Renewable Energy }\end{array}$ & $\begin{array}{l}\text { Strong political willingness to foster the } \\
\text { development of Renewable Energy }\end{array}$ \\
\hline & & $\begin{array}{l}\text { Lack of societal knowledge concerning } \\
\text { Sustainability and Renewable Energy }\end{array}$ & $\begin{array}{l}\text { Widespread knowledge about Sustainability and } \\
\text { Renewable Energy }\end{array}$ \\
\hline & & $\begin{array}{l}\text { Baseload capacity of renewable energy will stay } \\
\text { unrecognized }\end{array}$ & $\begin{array}{l}\text { Renewable energy will be considered as capable } \\
\text { for baseload }\end{array}$ \\
\hline & Consumer behaviour & $\begin{array}{l}\text { Lack of education concerning sustainable } \\
\text { consumption }\end{array}$ & $\begin{array}{l}\text { Widespread knowledge about sustainable } \\
\text { consumption }\end{array}$ \\
\hline \multirow{4}{*}{$\begin{array}{l}\text { Technology } \\
\text { and } \\
\text { Infrastructure }\end{array}$} & Energy Supply & Low diversification: gas, oil and hydropower & $\begin{array}{l}\text { High diversification of the energy matrix: } \\
\text { including solar, wind and biomass }\end{array}$ \\
\hline & $\begin{array}{l}\text { Demand } \\
\text { Consumption }\end{array}$ & $\begin{array}{l}\text { Use of imported oil derivates for transportation and } \\
\text { other sectors }\end{array}$ & $\begin{array}{l}\text { Electrify the economy in order to make use of } \\
\text { endogenous resources }\end{array}$ \\
\hline & \multirow[t]{2}{*}{ Import/export } & $\begin{array}{l}\text { Natural gas export prices are not benefiting the } \\
\text { national economy and Peruvian society - profits are } \\
\text { capture by private intermediaries. }\end{array}$ & $\begin{array}{l}\text { Natural gas prices are fair and benefiting Peruvian } \\
\text { society - profits are funding the energy } \\
\text { sustainability transition towards renewables }\end{array}$ \\
\hline & & Energy shortage - dependence of import & Excess supply -energy export \\
\hline & Productive matrix & Energy is not seen as an export product & $\begin{array}{l}\text { Renewable energy is part of the productive matrix } \\
\text { and an export product }\end{array}$ \\
\hline $\begin{array}{l}\text { Agenda } \\
\text { Intersection }\end{array}$ & International Affairs & $\begin{array}{l}\text { Plans, strategies and international commitments } \\
\text { developed for the Conference of the Parties } 20 \text { in } \\
\text { Lima under the UNFCCC are blocked by incumbents }\end{array}$ & $\begin{array}{l}\text { Plans, strategies and international commitments } \\
\text { are enabled and funded by international financial } \\
\text { mechanisms (Green Climate Fund) and private } \\
\text { investors }\end{array}$ \\
\hline
\end{tabular}

\section{Discussion}

As described above, (Avelino \& Rotmans, 2009) offer a framework for thinking about power in relation to 
transition management - and transition processes more generally. This framework refers to the power to innovate, including making issues more visible; the power to destroy or remove resources; the power to constitute, institute or stabilize a distribution of resources; and the power to transform the distribution of resources. Systemic power is defined as a combination of these capacities to act (ibid). To this we have added insights from empowerment-focused theorists (Narayan-Parker, 2005) and (Alsop, R., Bertelsen, M. F., \& Holland, 2006), who offer frameworks for the analysis of empowerment in relation to the creation of structures of opportunity and policy entrepreneurial agency at different levels. We now consider the participants' evaluation of the arena in these terms: to what extent does the arena support the empowerment of a professional community in order to exercise any of the above mentioned different types of power?

Overall, we judge that the transdisciplinary transition arena process implemented in Peru contributed to stakeholder empowerment in several ways. The arena can be viewed as an opportunity for social learning by mobilizing individual and collective assets and capabilities (Narayan-Parker, 2005), whereby different sectors pooled and shared their knowledge for the collective goal of envisaging and ideally catalysing energy system transformation. This involved the creation of an informal support network that is intended to strengthen the negotiation position, collective action and policy influence of the wider renewable energy sector in Peru by influencing the institutional climate and the socio-political structures at local, intermediary and state levels(Narayan-Parker, 2005)(Alsop, R., Bertelsen, M. F., \& Holland, 2006). Arguably these constitute a part of the innovative form of power that (Avelino \& Rotmans, 2009) refer to as the "capacity of actors to create or discover new resources". These consist of social and intellectual capital, i.e. new knowledge (problem, visions and strategies) and enhanced potential to take collective action, including by sharing resources among institutions. In terms of transformative power (changing the distribution of resources), the participatory process redistributed knowledge to marginalized actors, such knowledge normally being centralized in oligopolies of which the Peruvian energy sector is formed. In terms of constitutive power, the arena prepared ground for the informal institutionalization of a new network and the will to take collective action in future.

Of course this is far short of the systemic power (Avelino \& Rotmans, 2009). The Peruvian energy system will not directly change in response to marginal actors developing alternative visions, policy objectives and strategic measures. The system has its own path dependencies, with cognitive and investment lock-ins and vested interests that favour large scale, centralized supply, with renewable energy supply primarily constituted by large hydropower. Nonetheless, initiatives such as those described here arguably offer a step towards change, with capacity building, mobilization of knowledge resources and network building. Of course, the challenge will be in converting this through to further policy influence. For now, the capacity for destructive power (Avelino \& Rotmans, 2009), in the sense of path destabilization and creation, is not available to marginal actors - at least, not to any significant degree.

Overall, then, the main contribution of the transdisciplinary transition arena lies in contributing to the conditions necessary for empowerment of policy entrepreneurs, by stimulating the creation of an opportunity structure that has the potential to subsequently influence the contextual institutional climate and socio-political structures, catalysing assets and capabilities for inter-level agency (Narayan-Parker, 2005)(Alsop, R., Bertelsen, M. F., \& Holland, 2006). The TTMA contributes to the exercise of power not directly, but by helping, in a limited way, to provide access to resources (including knowledge), mobilization strategies, skills and willingness, all of which constitute a 'meta-condition' for the exercise of power (Avelino \& Rotmans, 2009). In this sense the arena can be understood as a political process that helps to ground rationally and knowledge-based empowerment for subsequent political activity. Its contribution is also psychological, helping to create meaning (purpose, vision) and self-determination (enhancing willingness to act) (Spreitzer, 1995), in addition to providing other forms of resource.

In short, in contrast to the discourse of (governance-oriented) transition management as a relatively depoliticized process intended to help societal exploration of new futures, the experimental transdisciplinary energy transition arena in Peru carves out the power of a tailored transdisciplinary and transition management approach for building up a normative, cognitive and organizational basis for entering the power game within an illiberal political context. In many ways this is not so different to transition management and transdisciplinary sustainability science fora applied in liberal western democracies, except for the political context.

\section{Conclusion}

The Peruvian energy system is one of concentrated, stable systemic power, with that power being held by a small number of actors. Despite a National Climate Change Strategy and renewable energy targets, progress towards a lower carbon energy system is both slow and is following path dependencies, including large scale hydropower 
and natural gas related technologies.

Participants in a transdisciplinary transition management arena (Noboa and Upham, 2018) envisaged a future energy model in which $100 \%$ of energy supply is based on renewable energy. Despite a preference for expanding decentralized renewable energy supply, the participants envisaged that large hydro would provide some fraction of electricity in future due to the long life-cycle of hydro plants, while fossil natural gas should be gradually reduced to zero. The latter reflects the participants' view that natural gas exploitation in Peru benefits only a small group of people. At the same time, the natural gas business is also negatively impacting the rainforest ecosystem, mainly due to the access roads that later influence the colonization, urbanization, land use change and deforestation. The same problem has been seen by the Hydropower projects, which are mainly centralized, impacting Amazonian River Basin ecosystems and concentrating power and investments in few hands. In terms of the natural resources required for a $100 \%$ renewable future, Peru's deserts were viewed by participants as a large, currently non-exploited resource for solar power production, much as Chile has invested in Solar power in the Atacama Desert, becoming from net importer to potential leader in South America in a short period of time. It was also highlighted that Peru's long coastline and desert also have the potential to support substantial wind-power (International Renewable Energy Agency, 2014) and that the social co-benefits are potentially higher for these types of power supply (depending on the modes of implementation) than for fossil natural gas and large hydro, which are associated with centralization of supply, management and ownership; corruption and environmental impact. The impacts of these latter forms of supply also include population displacement, potential lack of resilience in the face of changing, large scale water flow patterns, and corruption relating to the lack of royalties for those affected by resource exploitation and the lack of transparency regarding the state-private agreements for gas exploitation and trading (Ansar, Flyvbjerg, Budzier, \& Lunn, 2014).

Here we have instituted and assessed a policy arena for marginalized actors. The arena draws on the ideas of transition management and transdisciplinary sustainability, while the assessment draws on concepts or power and empowerment. While the former approaches use the relatively depoliticized discourse of systems terms, knowledge coproduction and societal reflexivity, both are normative in their goals of sustainability goals and social inclusivity and have the potential to empower and hence lead to the exercise of power.

In the present case, participants collectively developed a vision of a lower carbon, more decentralized and hence resilient national energy system; they generated shared problem statements, visions and strategies, building a coalition for change; and they were broadly satisfied with a process that we show in theory and practice has begun to empower them. While it remains to be seen how influential such arenas are in the medium and long term, such depoliticized sustainability discourse nonetheless has role to play in helping to legitimize informal institutional efforts towards environmental policy change.

\section{Declarations}

\subsection{Competing Interests}

The authors declare that they have no competing interests.

\subsection{Ethics Approval and Consent to Participate}

Via an ethical protocol, the participants gave informed consent to the use of information generated in the forum process. Conditions of anonymity have been adhered to.

\subsection{Consent for Publication}

There is no individually identifiable information in the paper.

\section{Acknowledgements}

The transdisciplinary transition management arena was co-funded by: the charitable foundation Friedrich-Ebert-Stiftung (FES-ILDIS), World Wild Fund (WWF), the Future Latin American Foundation (FFLA) and Leuphana University Lüneburg (Germany).

\section{References}

Alsop, R., Bertelsen, M. F., \& Holland, J. (2006). Empowerment in practice: From analysis to implementation: World Bank Publications. Retrieved from https://www.google.com/search?client=firefox-b\&ei=gu9ZW5bCOdOUmwX27J24Bg\&q=empowerment $+\mathrm{i}$ $\mathrm{n}+$ practice + alsop\&oq=empowerment + in + practice + alsop\&gs_l=psy-ab.3..33i160k112.27412.36435.0.37169 .33.25.1.0.0.0.263.2538.3j12j3.18.0.......1.1.64.psy-ab..14.18.2443...0

Ansar, A., Flyvbjerg, B., Budzier, A., \& Lunn, D. (2014). Should we build more large dams? The actual costs of 
hydropower megaproject development. Energy Policy, 69(Supplement C), 43-56. https://doi.org/10.1016/j.enpol.2013.10.069

Avelino, F., \& Rotmans, J. (2009). Power in transition: an interdisciplinary framework to study power in relation to structural change. European Journal of Social Theory, 12(4), 543-569.

Barber, B. (1984). Strong Democracy: Participatory Politics for a New Age. University of California Press, Berkley, California. https://doi.org/10.3817/1286070187

Batliwala, S., John, A. P., Schuler, S. R., Hashemi, S. M., Smith, C., McElnay, C., ... Leitmann, J. (1995). The meaning of womens empowerment: new concepts from action. FAMILY PLANNING NEWS, 11(1), pp.127-38. Retrieved from https://www.popline.org/node/635744?page=29

Berman, T. (2018). When knowledge is power: Grassroots participatory initiative as a process of resource development. WIT Press. from https://www.researchgate.net/profile/Tal_Berman/publication/322738736_When_knowledge_is_power_Gra ssroots_participatory_initiative_as_a_process_of_resource_development/links $/ 5 \mathrm{a} 6 \mathrm{c} 4 \mathrm{~d} 56 \mathrm{aca} 2722 \mathrm{c} 947 \mathrm{c} 29 \mathrm{~b} 9$ /When-knowledge-is-power-Grassroots-participatory-initiati

Bohman, J. (1996). Public Deliberation: Pluralism, Complexity, and Democracy. Metaphilosophy (Vol. 31).

Brandt, P., Ernst, A., Gralla, F., Luederitz, C., Lang, D. J., Newig, J., ... Von Wehrden, H. (2013). A review of transdisciplinary research in sustainability science. Ecological Economics, 92, 1-15. https://doi.org/10.1016/j.ecolecon.2013.04.008

Chavez-Rodriguez, M. F., Carvajal, P. E., Martinez Jaramillo, J. E., Egüez, A., Mahecha, R. E. G., Schaeffer, R., ... Arango Aramburo, S. (2018). Fuel saving strategies in the Andes: Long-term impacts for Peru, Colombia and Ecuador. Energy Strategy Reviews, 20, 35-48. https://doi.org/10.1016/J.ESR.2017.12.011

Chebet, A., Ruth, N., Nekesa, O. A., Ng'etich, W., Julius, K., \& Scholz, R. W. (2018). Efforts Toward Improving Maize Yields on Smallholder Farms in Uasin Gishu County, Kenya, through Site-specific, Soil-testing-based Fertiliser Recommendations: A Transdisciplinary Approach. East African Agricultural and Forestry Journal, 1-13. https://doi.org/10.1080/00128325.2018.1443413

Conger, J. A., \& Kanungo, R. N. (1988). The Empowerment Process: Integrating Theory and Practice. Academy of Management Review, 13(3), 471-482. https://doi.org/10.5465/amr.1988.4306983

Dedeurwaerdere, T. (2018). From ecological psychology to four varieties of post-positivism in transdisciplinary science. Environment Systems and Decisions. Retrieved from https://ink.springer.com/content/pdf/10.1007/s10669-017-9663-4.pdf

Dryzek, J. S. (1990). Discursive Democracy. Politics, Policy, and Political Science, 254.

Frantzeskaki, N., \& Kabisch, N. (2016). Designing a knowledge co-production operating space for urban environmental governance-Lessons from Rotterdam, Netherlands and Berlin, Germany. Environmental Science \& Policy, 62, 90-98. http://doi.org/10.1016/j.envsci.2016.01.010

Galinsky, A. D., Ku, G., \& Wang, C. S. (2005). Perspective-Taking and Self-Other Overlap: Fostering Social Bonds and Facilitating Social Coordination. Group Processes \& Intergroup Relations, 8(2), 109-124. https://doi.org/10.1177/1368430205051060

Geels, F. W., \& Schot, J. (2010). Reflections: Process Theory, Causality and Narrative Explanation. In Transitions to Sustainable Development: New Directions in the Study of Long Term Transformative Change (pp. 93-104). https://doi.org/10.4324/9780203856598

Hadorn, G. H., Bradley, D., Pohl, C., Rist, S., \& Wiesmann, U. (2006). Implications of transdisciplinarity for sustainability research. Ecological Economics, 60(1), 119-128.

Harris, F., \& Lyon, F. (2013). Transdisciplinary environmental research: Building trust across professional cultures. Environmental Science and Policy, 31. https://doi.org/10.1016/j.envsci.2013.02.006

Hernández, A. M. (2014). Strategic Facilitation of Complex Decision-Making. Springer.

Hölscher, K., Wittmayer, J. M., Avelino, F., \& Giezen, M. (2015). Opening up the transition arena: An analysis of (dis)empowerment of civil society actors in transition management in cities. Technological Forecasting and Social Change. https://doi.org/10.1016/j.techfore.2017.05.004

Hulme, M. (2009). Why we disagree about climate change: Understanding controversy, inaction and opportunity. Retrieved 
https://books.google.com/books?hl=en\&lr=\&id=DWMkb4ondbQC\&oi=fnd\&pg=PT1\&dq=hulme+2009\&o ts=s0xsq5KEhS\&sig=yE9USief4zNC8P7xesEJnZYW3Xo

Ibrahim, S., \& Alkire, S. (2007). Agency and empowerment: A proposal for internationally comparable indicators. Oxford Development Studies. https://www.tandfonline.com/doi/abs/10.1080/13600810701701897

International Renewable Energy Agency. (2014). Renewables Readiness Assessment: Peru, (November), 1-72.

Jahn, T. (2008). Transdisciplinarity in the practice of research. Transdisziplinäre Forschung: Integrative Forschungsprozesse Verstehen Und Bewerten. Campus Verlag, Frankfurt/Main, Germany, 21-37.

Kemp, R., Loorbach, D., \& Rotmans, J. (2007). Transition management as a model for managing processes of co-evolution towards sustainable development, 14, 1-15.

Kenis, A., Bono, F., \& Mathijs, E. (2016). Unravelling the (post-) political in transition management: Interrogating pathways towards sustainable change . Journal of Environmental Policy \& Planning.

Kerr, N. L., \& Tindale, R. S. (2004). Group performance and decision making. Annu Rev Psychol, 55, 623-655. https://doi.org/10.1146/annurev.psych.55.090902.142009

Klein, J. T., Grossenbacher-Mansuy, W., Haberli, R., Bill, A., Scholz, R. W., \& Welti, M. (2001). Transdisciplinarity: joint problem solving among science, technology, and society. An effective way for managing complexity. In Transdisciplinarity: joint problem solving among science, technology, and society. Proceedings of the International Transdisciplinarity 2000 conference (Zurich: Haffmans sachbuch Verlag, 2000). https://doi.org/10.1007/978-3-0348-8419-8

Leach, M., Rockström, J., Raskin, P., Scoones, I., Stirling, A. C., Smith, A., \& Thompson, J. (2012). Transforming Innovation for Sustainability, 17(2).

Lewin, K. (1945). Resolving social conflicts. Retrieved from http://krishikosh.egranth.ac.in/bitstream/1/17809/1/IVRI B 529.pdf

Loorbach, D., \& Rotmans, J. (2010). The practice of transition management: Examples and lessons from four distinct cases. Futures, 42(3), 237-246. https://doi.org/10.1016/j.futures.2009.11.009

Luederitz, C., Schäpke, N., Wiek, A., Lang, D. J., Bergmann, M., Bos, J. J., ... Westley, F. R. (2016). Learning through evaluation - A tentative evaluative scheme for sustainability transition experiments. Journal of Cleaner Production. https://doi.org/10.1016/j.jclepro.2016.09.005

Malhotra, A., \& Cross, S. S. (2005). Women's empowerment as a variable in international development. World Bank Library. Retrieved from https://elibrary.worldbank.org/doi/pdf/10.1596/0-8213-6057-4\#page=93

Meadowcroft, J. (2009). What about the politics? Sustainable development, transition management, and long term energy transitions. Policy Sciences, 42(4), 323-340. https://doi.org/10.1007/s11077-009-9097-z

Meadowcroft, J. (2011). Engaging with the politics of sustainability transitions. Environmental Innovation and Societal Transitions, 1(1), 70-75. http://doi.org/10.1016/J.EIST.2011.02.003

MINAM. (2014). Estrategia Nacional ante el Cambio Climático. Gobierno de la República.

Narayan-Parker, D. (2005). Measuring Empowerment : Cross-Disciplinary Perspectives. World Bank. Retrieved from

https://www.google.com/search?client=firefox-b\&ei=fO9ZW7OgFcna6AT867r4DQ\&q=measurement+emp owerment + Narayan\&oq $=$ measurement + empowerment + Narayan\&gs_l$=$ psy-ab.3..0i22i30k1.4094.5310.0.55 50.8.8.0.0.0.0.191.521.0j4.4.0...0...1.1.64.psy-ab..4.4.520...0.FnrHyidq

Njoroge, R., Birech, R., Arusey, C., Korir, M., Mutisya, C., \& Scholz, R. W. (2015). Transdisciplinary processes of developing, applying, and evaluating a method for improving smallholder farmers' access to (phosphorus) fertilizers: the SMAP method. Sustainability Science. https://doi.org/10.1007/s11625-015-0333-5

Noboa, E., \& Upham, P. (2018). Energy policy and transdisciplinary transition management arenas in illiberal democracies: A conceptual framework. Energy Research \& Social Science, 46, 114-124. https://doi.org/10.1016/J.ERSS.2018.07.014

Patterson, J., Schulz, K., Vervoort, J., van der Hel, S., Widerberg, O., Adler, C., ... Barau, A. (2017). Exploring the governance and politics of transformations towards sustainability. Environmental Innovation and Societal Transitions, 24, 1-16. https://doi.org/10.1016/j.eist.2016.09.001

Popa, F., Guillermin, M., \& Dedeurwaerdere, T. (2015). A pragmatist approach to transdisciplinarity in 
sustainability research: From complex systems theory to reflexive science. Futures, 65 . https://doi.org/10.1016/j.futures.2014.02.002

Reicher, S., Spears, R., \& Haslam, S. A. (2010). The social identity approach in social psychology. Sage Identities Handbook, 45-62.

Ríos Villacorta, A. (2016). Estudio: Futuro de la Energía en Perú: Estrategias energéticas sostenibles.

Schellnhuber, H. J., Messner, D., Leggewie, C., Leinfelder, R., Nakicenovic, N., Rahmstorf, S., ... Schubert, R. (2011). World in transition: a social contract for sustainability. Berlin: German Advisory Council on Global Change (WBGU)(Flagship Report).

Scholz, R. W. (2017). The Normative Dimension in Transdisciplinarity, Transition Management, and Transformation Sciences: New Roles of Science and Universities in Sustainable Transitioning. Sustainability, 9(6), 991.

Scholz, R. W., Binder, C. R., Brand, F., Gallati, J., Lang, D. J., Bao Le, Q., ... Stauffacher, M. (2011). Environmental literacy in science and society: From knowledge to decisions. Environmental Literacy in Science and Society: From Knowledge to Decisions. https://doi.org/10.1017/CBO9780511921520

Scholz, R. W., Lang, D. J., Wiek, A., Walter, A. I., \& Stauffacher, M. (2006). Transdisciplinary case studies as a means of sustainability learning: Historical framework and theory. International Journal of Sustainability in Higher Education, 7(3), 226-251.

Scholz, R. W., \& Steiner, G. (2015a). The real type and ideal type of transdisciplinary processes: part $\begin{array}{llll}\text { I-theoretical foundations. } & \text { Sustainability } & \text { Science, } & 10(4),\end{array}$ https://doi.org/10.1007/s11625-015-0326-4

Scholz, R. W., \& Steiner, G. (2015b). Transdisciplinarity at the crossroads. Sustainability Science, 10(4), 521526. https://doi.org/10.1007/s11625-015-0338-0

Scholz, R. W., \& Tietje, O. (2002). Embedded case study methods: Integrating quantitative and qualitative knowledge. Sage.

Schulz, K., \& Siriwardane, R. (2015). Depoliticised and technocratic? Normativity and the politics of transformative adaptation. Earth Systems Governance Working Paper No.33.

Scoones, I., Leach, M., \& Newell, P. (2015). The politics of green transformations. Retrieved from https://books.google.com/books?hl=en\&lr=\&id=3X8cBgAAQBAJ\&oi=fnd\&pg=PP1\&dq=Scoones + et + al., $+2015 \&$ ots $=$ L2tzV9boxD\&sig=fDVLe4Vtxh058j5q1e8gfleajCw

Spreitzer, G. M. (1995). Psychological empowerment in the workplace. Academy of Management Journal, 38(5), 1442-1465. https://doi.org/10.2307/256865

Steelman, T., Nichols, E. G., James, A., Bradford, L., Ebersöhn, L., Scherman, V., ... McHale, M. R. (2015). Practicing the science of sustainability: the challenges of transdisciplinarity in a developing world context. Sustainability Science. https://doi.org/10.1007/s11625-015-0334-4

Stirling, A. (2011). Pluralising progress: From integrative transitions to transformative diversity. Environmental Innovation and Societal Transitions, 1(1), 82-88.

Stirling, A. (2014). Transforming power: Social science and the politics of energy choices. Energy Research \& Social Science, 1, 83-95. http://doi.org/10.1016/J.ERSS.2014.02.001

Stokols, D., Fuqua, J., Gress, J., Harvey, R., Phillips, K., Baezconde-Garbanati, L., \& Unger, J. (2003). Evaluating transdisciplinary science. Nicotine \& Tobacco Research, (5/1), S21-S39. Retrieved from https://academic.oup.com/ntr/article-abstract/5/Suppl_1/S21/1047622

Swyngedouw, E. (2010). Apocalypse Forever? Theory, Culture \& Society, 27(2-3), 213-232. https://doi.org/10.1177/0263276409358728

Thomas, E. F., McGarty, C., \& Mavor, K. I. (2009). Aligning identities, emotions, and beliefs to create commitment to sustainable social and political action. Pers Soc Psychol Rev, 13(3), 194-218. https://doi.org/10.1177/1088868309341563

Van den Bergh, J. C. J. M., Truffer, B., \& Kallis, G. (2011). Environmental innovation and societal transitions: Introduction and overview. Environmental Innovation and Societal Transitions, 1(1), 1-23.

Vilsmaier, U., Engbers, M., Luthardt, P., Maas-Deipenbrock, R. M., Wunderlich, S., \& Scholz, R. W. (2015). Case-based mutual learning sessions: knowledge integration and transfer in transdisciplinary processes. 
Sustainability Science, 10(4), 563-580.

Walter, A. I., Helgenberger, S., Wiek, A., \& Scholz, R. W. (2007). Measuring societal effects of transdisciplinary research projects: Design and application of an evaluation method. Evaluation and Program Planning, 30(4), 325-338. https://doi.org/10.1016/J.EVALPROGPLAN.2007.08.002

Wiek, A., Claudia, B., \& Scholz, R. W. (2006). Functions of scenarios in transition processes. Futures, 38(7), 740-766. Retrieved from https://www.sciencedirect.com/science/article/pii/S0016328705002144

\section{Copyrights}

Copyright for this article is retained by the author(s), with first publication rights granted to the journal.

This is an open-access article distributed under the terms and conditions of the Creative Commons Attribution license (http://creativecommons.org/licenses/by/4.0/). 